\title{
15. REWORKED FOSSILS IN MESOZOIC AND CENOZOIC PELAGIC CENTRAL PACIFIC OCEAN SEDIMENTS, DEEP SEA DRILLING PROJECT SITES 463, 464, 465, AND 466, LEG 62 1
}

\author{
Jörn Thiede, Department of Geology, University of Oslo, Blindern, Oslo 3, Norway \\ Anne Boersma, Lamont-Doherty Geological Observatory, Columbia University, Palisades, New York \\ Ronald R. Schmidt, Institute of Earth Sciences, University of Utrecht, Utrecht 3508 TA, The Netherlands \\ and \\ Edith Vincent, Scripps Institution of Oceanography, La Jolla, California
}

\begin{abstract}
Upper Mesozoic and Cenozoic sediments penetrated at deep-sea drill sites in the tropical and subtropical central Pacific Ocean often contain discrete horizons with reworked and displaced biogenic sediment components which can include fossils produced by benthic organisms living in neritic environments and by oceanic plankton. All four drill sites of Deep Sea Drilling Project Leg 62 in the central North Pacific Ocean received an influx of benthic shallow-water fossils during the late Mesozoic, and of planktonic as well as shallow-water benthic fossils during the Cenozoic. In general, reworked and displaced sediment components from these two widely different source areas occur in discrete horizons and separate from each other, although in certain instances they have been observed together. The flux of shallow-water components to the deep sea is almost entirely restricted to eight intervals of low eustatic sea-level stands during late Mesozoic and Cenozoic times. Non-contemporaneous pelagic-fossil assemblages which indicate reworking in intermediate and deep waters are restricted to the Cenozoic sections of the Leg 62 sites, whereas they have not been noted in the Mesozoic parts of the penetrated sedimentary sequences. A similar difference of pre-Maastrichtian and Maastrichtian-Pleistocene sections has been observed elsewhere in the central Pacific Ocean. This difference seems to point to a fundamental change from a very quiet and sluggish bottom-water circulation during pre-Maastrichtian time to a Maastrichtian and Cenozoic paleoenvironment when currents in the intermediate and deep waters eroded wide regions of the central Pacific Ocean.
\end{abstract}

\section{INTRODUCTION}

Relatively homogeneous deep-sea sediments often contain reworked and displaced contemporaneous and non-contemporaneous older fossils. These occurrences document times of erosion which remobilized neritic and pelagic sediments. A careful analysis of the occurrence of such reworked material is expected to offer important information about the vertical and horizontal transport of sediment components, either within the same water mass or across oceanic water-mass boundaries. Since reworking implies mechanical transport of the fossil material, the occurrence of reworked sediment components supplies us with an argument of unique simplicity which has not yet been used extensively in paleoceanography. Although reworked fossil material occasionally is enriched in certain intervals, it usually represents only a minor fraction of the total pelagic sediment. Such fossils therefore are often overlooked, underrated, and not studied in detail during determination of the biostratigraphy and(or) the depositional environment of the Mesozoic and Cenozoic sedimentary sequences penetrated at oceanic drill sites. The distribution of such fossil material which is foreign to its host sediment has only recently received more attention, because it could be used to document (1) long-distance transport paths of deep-sea currents across the ocean

\footnotetext{
${ }^{1}$ Initial Reports of the Deep Sea Drilling Project, Volume 62.
}

floor (Burckle and Stanton, 1975; van Andel, 1973; Thiede, 1977); (2) erosion of older pelagic sediment sequences (Riedel, 1971); and (3) the effect of global sealevel changes on the pelagic environment (Premoli Silva and Boersma, 1977).

Because of their scarcity, displaced fossils in samples from deep-sea drill sites only rarely have received the attention they deserve. Only recently, the studies of Beckmann (1975), Boltovskoy (1977), Cook et al. (1975), Premoli Silva and Boersma (1977), Premoli Silva and Brusa (1981), and Rea and Thiede (1981) have laid some ground work for systematically collecting the valuable information which can be obtained by studying carefully and in great detail the stratigraphic distribution and composition of reworked and displaced biogenic deep-sea sediment components. These studies are important because they provide detailed stratigraphic and paleontologic data about the host sediment containing the displaced material, as well as about the displaced fossils themselves. The analysis of processes controlling the erosion and flux of reworked material to and from the ocean floor can therefore now be carried out in a much more systematic manner than before. Using the existing data base we want to discuss occurrences of displaced pelagic and shallow-water benthic fossils found at all four drill sites of DSDP Leg 62 in the central North Pacific Ocean (Fig. 1).

In Table 1, we have tried to categorize the type of information which can be gained from the study of displaced and reworked fossil material which has been ob- 


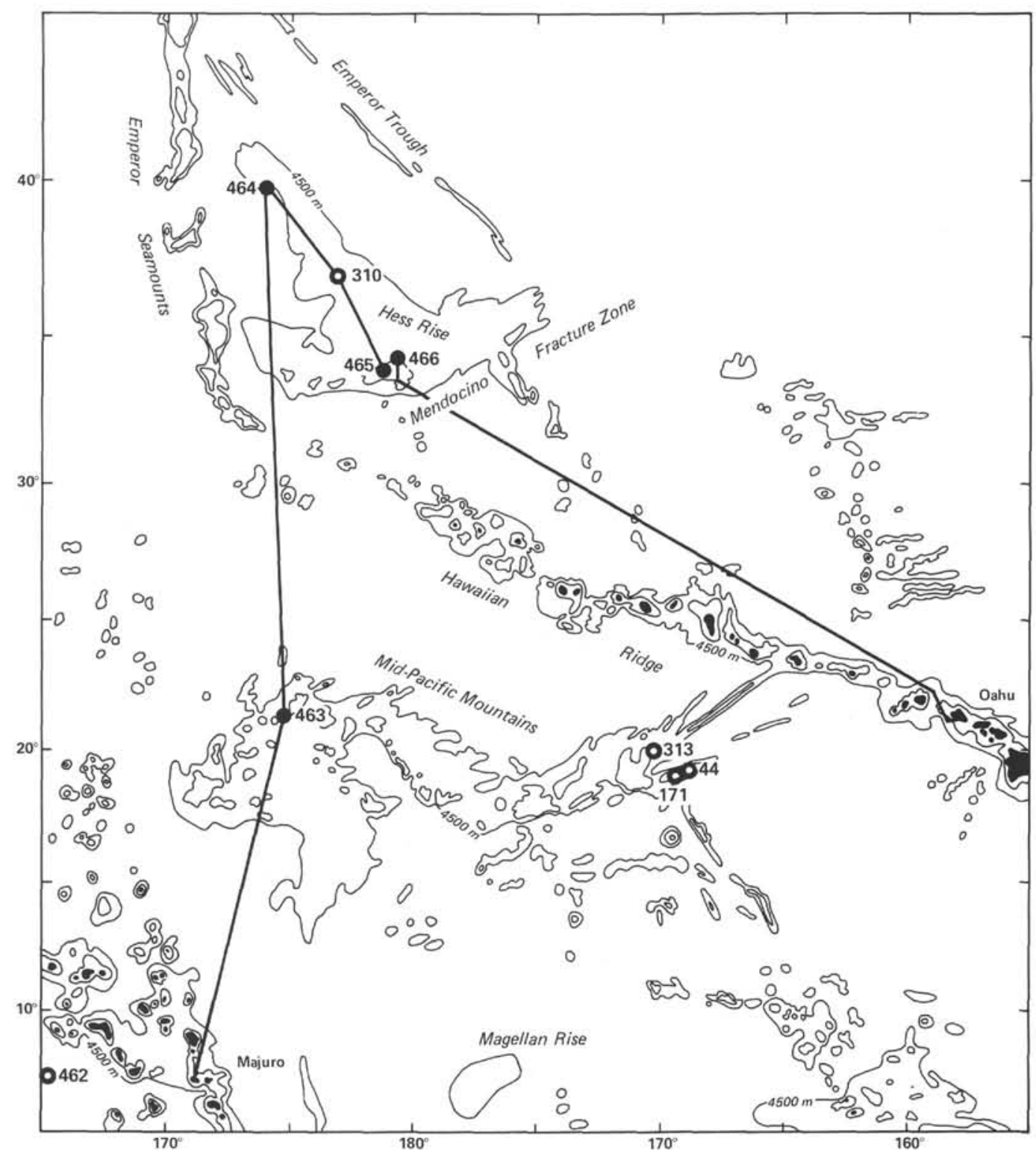

Figure 1. DSDP sites on the Mid-Pacific Mountains and on Hess Rise, central North Pacific Ocean.

Table 1. Reworked and displaced fossils in pelagic sediments.

\begin{tabular}{|c|c|c|c|}
\hline & \multirow{2}{*}{$\begin{array}{l}\text { Shallow-Water } \\
\text { Benthic Fossils }\end{array}$} & \multicolumn{2}{|c|}{ Planktonic Fossils } \\
\hline & & Calcareous & Siliceous \\
\hline $\begin{array}{l}\text { Contempo- } \\
\text { raneous }\end{array}$ & $\begin{array}{l}\text { Water depth and nature of } \\
\text { adjacent shallow-water } \\
\text { environments } \\
\text { (paleogeography, } \\
\text { paleobathymetry, } \\
\text { paleobiogeography) } \\
\text { Mode of transport } \\
\text { Timing of global sea- } \\
\text { level low stands } \\
\text { Subsidence }\end{array}$ & $\begin{array}{l}\text { Current regimes in the } \\
\text { depositional } \\
\text { environment } \\
\text { Amount of down-slope } \\
\text { transport (espe- } \\
\text { cially displacement } \\
\text { into different } \\
\text { dissolution facies) }\end{array}$ & $\begin{array}{l}\text { Current regimes in the } \\
\text { depositional } \\
\text { environment } \\
\text { Long-distance bottom- } \\
\text { water transport }\end{array}$ \\
\hline $\begin{array}{l}\text { Non- } \\
\text { contempo- } \\
\text { raneous }\end{array}$ & $\begin{array}{l}\text { Water depth and nature of } \\
\text { shallow-water } \\
\text { environments older } \\
\text { than host sediment } \\
\text { Mode of transport } \\
\text { Timing and amount of } \\
\text { global sea-level } \\
\text { changes }\end{array}$ & $\begin{array}{l}\text { Nature and stra- } \\
\text { tigraphy of eroded } \\
\text { pelagic sediment } \\
\text { section (mostly in } \\
\text { intermediate waters } \\
\text { above the CCD) } \\
\text { Current regimes in the } \\
\text { depositional } \\
\text { environments }\end{array}$ & $\begin{array}{l}\text { Nature and stra- } \\
\text { tigraphy of eroded } \\
\text { pelagic sediment } \\
\text { section (mostly } \\
\text { deep water below } \\
\text { the CCD) } \\
\text { Current regimes in the } \\
\text { depositional } \\
\text { environment }\end{array}$ \\
\hline
\end{tabular}

served frequently in Mesozoic and Cenozoic deep-sea sediments. Such material often is concentrated in discrete intervals or horizons. Shallow-water benthic and planktonic fossils often are found separate from each other, although in certain instances they have been observed together. In Table 1 , we discriminate between fossils which are reworked and displaced, but which apparently are of the same age as the host sediment (contemporaneous) and those which are clearly older (noncontemporaneous) and which therefore represent erosion and remobilization of stratigraphic sequences laid down prior to deposition of the host sediment. Both types of occurrences offer insight into the depositional environment of the host sediment, as well as that of the reworked, displaced components. The transport of the biogenic grains from their original to their final depo- 
sitional site requires mechanical transport by currents (turbidity currents, slumps, bottom-water currents) along the bottom of the ocean. If, for example, shallow-water benthic fossils are found in deep waters, or if calcareous material is found below the CCD, both had to cross physically important water-mass boundaries. Therefore, the hydrodynamic properties of the host sediment, as well as of the displaced material, offer at least qualitative, if not quantitative, information about the shallow and deep-water current regimes of the ocean.

Displaced shallow-water fossils found in pelagic sediments are easily recognized whether the material is contemporaneous with or older than the host sediment. Displaced shallow-water fossils reveal the presence and nature of former neritic depositional environments (shoals or coastal regions of oceanic islands and land masses) which might no longer exist, because of subsidence of the oceanic crust. They allow us to date the existence and subsidence of these environments, and to describe their mode of transport and in some instances the morphology of the transport path. As will be shown later, their flux to the deep ocean is dominantly confined to times of low global sea-level stands.

The presence of reworked and displaced contemporaneous pelagic sediment components is often difficult to detect, because of the apparently homogeneous nature of many deep-sea sediments and because displaced coeval pelagic fossils cannot easily be distinguished from the autochthonous fossil assemblages. However, we know from observations of modern oceanfloor features (Seibold, 1978) that recent deep-sea sediments often are affected by bottom-water currents. The textural properties of deep-sea sediments (van Andel, 1973) and sedimentary structures encountered in cores obtained from deep-sea drill sites suggest that this also happened in the past, although we often have difficulties in evaluating the importance and the proportions of the reworked material. Besides sedimentary structures typical of current transport, the presence of calcareous material at water depths far below the CCD can be assumed to indicate current transport.

Displaced, non-contemporaneous pelagic sediment components are much easier to evaluate than contemporaneous material. They offer information about the nature, stratigraphy, depth of deposition, and source of the eroded sediment section, and about the current regimes of the depositional environments of the host sediment. Calcareous pelagic material has been eroded mostly from intermediate (deeper than neritic, but shallower than $\mathrm{CCD}$ ) waters, pure siliceous displaced fossil assemblages from regions below the CCD. The spread in age of the reworked material also allows reconstruction of the span of the eroded stratigraphic sequence.

\section{STRATIGRAPHY OF LEG 62 DRILL SITES AND THE OCCURRENCE OF DISPLACED SEDIMENT COMPONENTS}

The four drill sites of DSDP Leg 62 (Fig. 1) are situated on the Mid-Pacific Mountains (Site 463) and on Hess Rise (Sites 464, 465, and 466), in the central North Pacific Ocean. At all four locations, sedimentary se- quences of late Mesozoic and Cenozoic age were penetrated and found to contain displaced and reworked shallow-water benthic and pelagic fossils (Table 2; Fig. 2 ). Because of the presence of long-lasting hiatuses, the sequences (with the possible exception of Site 464 on northern Hess Rise) do not document the continuous evolution of their depositional environment.

Site 463 (western Mid-Pacific Mountains) is situated in 2525 meters of water, where a dominantly calcareous sequence of oozes, chalks, and limestones ranging in age from Barremian to Pleistocene was penetrated (Fig. 2). Lithologic variations of these calcareous deposits allow us to subdivide them into four major units. The oldest unit consists of more than 190 meters of pelagic limestone interbedded with shallow-water carbonate debris which occurs with increasing abundance down-core (Fig. 3). The overlying unit is 45 meters thick and is composed of cyclic, in part carbonaceous limestones of early Aptian age, with a number of distinct, dark volcanic-ash horizons. The organic-carbon content of the individual carbonaceous horizons reaches values in excess of $4 \%$ (Dean et al., this volume). The two younger units consist of Aptian to middle Albian multicolored pelagic-limestone beds, with chert as a common component, and upper Albian to Pleistocene nannofossil and foraminifer oozes and chalks, as well as some limestone. Hiatuses interrupt the younger two units in several places, and calcareous faunas and floras show signs of severe dissolution, despite the shallow location of the site.

Reworked and displaced sediment components have been found both in the Mesozoic and the Cenozoic parts of the sequence penetrated at Site 463 . The variation in preservation of radiolarian skeletons; the low-diversity assemblages; the sorting of abundant, well-preserved, spherical tests; and the fragmentation of all nassellarian tests suggest displacement of coeval radiolarian faunas during the Barremian. Middle Miocene to Cretaceous planktonic foraminifers were found in Core 4 (upper Miocene). Pliocene calcareous nannofossils occur in the Quaternary sediments of Cores 1 and 2; Miocene to Eocene nannofossils occur in Core 4 (upper Miocene); and Eocene nannofossils occur in Core 6 (Oligocene). Displaced shallow-water components include large benthic foraminifers in Cores 8-12,16, 20,22, 23, 37, 38, and 49. The interbedded clastic limestones of Lithologic Unit IV (Fig. 3) are composed of shallow-water carbonates which contain oolites, mollusk and echinoderm fragments, stromatolites and algal fragments, and large foraminifers (Ferry and Schaaf, this volume).

Sites 464, 465, and 466 were drilled on Hess RiseSite 464 in 4637 meters of water on the western flank of its northern tip, and Sites 465 and 466 adjacent to each other at depths of 2161 and 2665 meters, respectively, along the southern boundary of Hess Rise, which follows the Mendocino Fracture Zone. Coring at these sites sampled not only widely distinct parts of Hess Rise, but also water depths spanning more than 2500 meters. Surprisingly, the sediments encountered at all three sites range in age to just over 100 m.y., but their lithologies are distinct because of the difference in location and 
Table 2. Distribution of hiatuses and reworked fossil material at sites of DSDP Leg 62 in the central North Pacific Ocean.

\begin{tabular}{|c|c|c|c|c|c|}
\hline \multirow[b]{2}{*}{ Site } & \multirow[b]{2}{*}{$\begin{array}{l}\text { Water Depth } \\
\text { (m) }\end{array}$} & \multirow[b]{2}{*}{$\begin{array}{c}\text { Hiatuses } \\
(\mathrm{m} . \mathrm{y})\end{array}$} & \multirow[b]{2}{*}{$\begin{array}{c}\text { Age of Host Sediment } \\
(\mathrm{m} . \mathrm{y})\end{array}$} & \multicolumn{2}{|c|}{ Reworked Sediment Components } \\
\hline & & & & $\begin{array}{l}\text { Age of Shallow-Water } \\
\text { Fossils (m.y.) }\end{array}$ & $\begin{array}{l}\text { Age of Pelagic } \\
\text { Fossils (m.y.) }\end{array}$ \\
\hline \multirow[t]{6}{*}{463} & 2525 & $11-27,50-67$ & Plio-Pleistocene & & Pliocene \\
\hline & & & Late Miocene & & Cretaceous-Miocene \\
\hline & & & Oligocene & & Eocene \\
\hline & & & Maastrichtian & Contemporaneous & \\
\hline & & & Cenomanian & Contemporaneous & \\
\hline & & & Barremian-Aptian & Contemporaneous & \\
\hline \multirow[t]{3}{*}{464} & 4637 & & Late Maastrichtian & Contemporaneous & \\
\hline & & & $\begin{array}{l}\text { Santonian-late } \\
\text { Campanian }\end{array}$ & Contemporaneous & \\
\hline & & & Early Albian-Cenomanian & Contemporaneous & \\
\hline \multirow[t]{3}{*}{465} & 2161 & $2-54,73-92$ & $\begin{array}{l}\text { Late Maastrichtian- } \\
\text { Pliocene }\end{array}$ & Contemporaneous & Eocene-Paleocene \\
\hline & & & $\begin{array}{l}\text { Coniacian-late } \\
\text { Campanian }\end{array}$ & Contemporaneous & \\
\hline & & & $\begin{array}{l}\text { Early Cenomanian-late } \\
\text { Albian }\end{array}$ & Contemporaneous & Contemporaneous \\
\hline \multirow[t]{4}{*}{466} & 2655 & $5-39,48-70,85-100$ & Pliocene & & $\begin{array}{l}\text { Late Miocene-late } \\
\text { Cretaceous }\end{array}$ \\
\hline & & & Late-middle Miocene & & Eocene-Cretaceous \\
\hline & & & Coniacian-late Turonian & Contemporaneous & \\
\hline & & & Late Albian & Contemporaneous & \\
\hline
\end{tabular}

water depths. Because of the location on crust well north of the equator for most of the past 100 m.y., and because of the depth, most of the sediments of Site 464 deposited during the past 95 m.y. consist of brown clays or clayey siliceous oozes to siliceous clays. This part of the sequence is particularly difficult to date, because of the scarcity of fossils, although siliceous fossils in the youngest part (Sancetta, this volume) and fish bones and scales in its older part (Doyle and Riedel, this volume) have allowed gross age assignments. These biostratigraphies do not allow precise definitions of hiatuses, and overall accumulation rates therefore remain very low. However, the oldest intervals of the deposits sampled at Site 464 are chert, chalk, and marlstone of mid-Cretaceous age, which accumulated rapidly when the site was crossing beneath the equatorial highproductivity zone (Lancelot and Larson, 1975; Lancelot, 1978). The reworked material at Site 464 is restricted to large benthic foraminifers found in Core 27 (Albian).

Holes 465 and $465 \mathrm{~A}$, on southern Hess Rise, penetrated a Pleistocene to upper Albian sequence of calcareous oozes and chalk above a highly altered, possibly subaerially extruded (Seifert et al., this volume) trachyte basement. Outstanding sedimentary features of this site are the olive-gray, laminated upper Albian to Cenomanian limestones that in places have high contents of organic carbon, and the apparently complete section across the Cretaceous/Tertiary boundary (Boersma, this volume). The continuity of the overlying sequence of Cenozoic calcareous ooze is interrupted by a long lasting (>50-m.y.) hiatus. The possibly subaerially extruded volcanic basement and the benthic fossils preserved in the older parts of the section document a location of this site close to the Albian sea surface and enable a well-controlled reconstruction of the depositional paleoenvironment along southern Hess Rise.

The olive-gray, laminated upper Albian to lower Cenomanian limestones penetrated at the base of the Site 465 sedimentary sequence display a considerable number of sedimentary structures indicative of bottom- water currents. Contemporaneous radiolarians are enriched in thin layers, and the sediments appear to have undergone considerable sorting. Reworked and displaced non-contemporaneous fossils are restricted to the Cenozoic interval of Site 465. Below the lower Pliocene sediments, a mixed zone contains lower Eocene and upper Paleocene sediments mixed with lower and upper Pliocene sediments. It is remarkable that the over-100cm-thick layer of the "'G. " eugubina Zone just above the Cretaceous/Tertiary boundary did not appear to contain any reworked material.

Displaced shallow-water carbonate fossils consist of fragments of Inoceramus (Fig. 4) and large neritic benthic foraminifers. Inoceramus fragments have been found in Cores 9, 13, 25, 27, and 28, of late Albian to Maastrichtian age. The large neritic foraminifers have been observed in many cores of both the Mesozoic and Cenozoic parts of the Site 465 sedimentary column. They were commonly found in cores belonging to the upper Maastrichtian M. mura Zone, the upper Campanian $T$. trifidus Zone, the Santonian $G$. concavata-G. elevata Zones, and throughout the lower Cenomanian to upper Albian laminated-limestone sequence. They also have been observed in the upper Paleocene cores of Holes 465 and $465 \mathrm{~A}$.

Site 466 also is on southern Hess Rise, but in somewhat deeper water than Site 465 , which is about $50 \mathrm{~km}$ to the southwest. The stratigraphic sequence at Site 466 is very similar to that at Site 465 , consisting of a largely calcareous section with a basal unit of olive-gray, organic-carbon-rich nannofossil chalk and limestone of late Albian and early Cenomanian age. The overlying sequence is nannofossil ooze with some chert in its oldest part, but the continuity of this sequence is interrupted by two hiatuses which span 4 to $38 \mathrm{~m}$.y. and 48 to $70 \mathrm{~m} . \mathrm{y}$.

Shallow-water fossils from Site 466 occur only in the Upper Cretaceous deposits and include fragments of Inoceramus (Cores 9-11, 19, and 21), which have been observed in many other deep-sea drill sites (Thiede and Dinkelman, 1977), a large orbitoidal shallow-water ben- 
thic foraminifer (Core 25,CC), and unrecrystallized ornamented benthic foraminifers (Cores 29 and 31), which are believed to be displaced.

A Pliocene interval from Core 7 (Section 4) to Core 8 (Section 1) of Site 466 showed reworking of planktonic foraminifers and calcareous nannofossils from middle and upper Miocene, upper Oligocene, middle to upper Eocene, and Upper Cretaceous pelagic sediments. The planktonic foraminifers of the upper and middle Eocene nannofossil ooze of Cores 8 to 10 show reworking of Eocene, Paleocene, and Cretaceous species. The admixed Cretaceous components are derived from Maastrichtian and upper Campanian sediments. The presence of reworked, excellently preserved specimens of Globotruncana calcarata is important, because this fossil does not occur in the upper Campanian sediments penetrated deeper in this hole, and because upper Campanian foraminifers are only moderately well preserved. These observations point to a source farther up-slope and point to the regional scope of reworking processes. Very little reworking has been noted in the Pleistocene sediments.

\section{OTHER OCCURRENCES OF REWORKED AND DISPLACED FOSSILS IN THE TROPICAL AND SUBTROPICAL PACIFIC OCEAN}

All four sites of Leg 62 had been selected to typify the depositional paleoenvironments along the elevated portions of aseismic rises in regions of the North Pacific Ocean where such information had not been available. Data from these sites therefore have to be seen in conjunction with information collected during the earlier DSDP cruises in the region. The unexpected long-lasting hiatuses in the Cenozoic of the four Leg 62 sites and horizons containing large amounts of displaced, in part older, material have made it difficult to interpret the sedimentary history at these locations completely. A search therefore has been made in the reports of the preLeg 62 drill sites in the tropical and subtropical Pacific Ocean, in the hope of establishing temporal and spatial patterns of the distributions of reworked and displaced contemporaneous and non-contemporaneous shallowwater calcareous and pelagic fossils. The observations reported in the drill-site records are of widely varying character, both quantitatively and qualitatively; they are listed in Table 3. Their spatial distribution is shown on Figure 5, and their age distribution and the difference of the ages of the reworked components and their host sediments are plotted on Figures 6 and 7 . However, reworked material has not been reported from some drill sites, either because there was none, or because it has been overlooked. The ages used in this compilation are based on the numerical time scales of van Hinte (1976), Hardenbol and Berggren (1978), and Berggren and Van Couvering (1974).

The described sediments of these sites (Table 3 ) span a long time (from late Jurassic/early Cretaceous to Quaternary) and a wide depth range ( $>1.5$ to $<6 \mathrm{~km})$; and most sites are on the Mesozoic part of the Pacific Plate. However, because of the poor coring record of sites drilled during the early phases of the Deep Sea Drilling Project, and because of the long-lasting hia- tuses which have been encountered, the deep-sea-basin sites from the central Pacific Ocean are under-represented in comparison to elevated areas. The sites cover the entire western subtropical and tropical Pacific Ocean, whose sea floor is dominantly of Jurassic, Cretaceous, and early Tertiary age (Pitman et al., 1974). Because of the random regional distribution of the drill site locations (Fig. 5) of such a wide area, a bias toward one deep-sea basin or toward one very specialized depositional environment can be excluded.

\section{Occurrence and Composition of Shallow-Water Fossils in Deep-Sea Sediments from the Tropical and Subtropical Pacific Ocean}

The occurrence and age distribution of displaced shallow-water sediment components (Fig. 6) at many deep-sea drill sites of the western central Pacific Ocean comes as a surprise, because these sites are at a distance from extensive land areas. However, it has been known for some time that many of the submarine rises and platforms in the western central Pacific Ocean formerly reached close to or above the sea surface. Because shallow-water carbonate rocks have been dredged from their flanks (Matthews et al., 1974; Hamilton, 1956) at water depths of several hundreds to several thousands of meters (Heezen et al., 1973), these highs indeed may have served as sources of such displaced material.

Evidence for displacement of shallow-water carbonate fossils from their original depositional environment into the adjacent deep sea represents wide intervals in both space and time (Table 3). Most of the occurrences document the displacement of sediments of approximately the same age as the host sediment, whereas evidence for erosion of sections considerably antedating the time of displacement have been found in very few instances. These sites are close to the Tuamotu Islands (Site 76), close to the Line Islands (Site 165), close to the Emperor Seamounts (Site 309), and in the Nauru Basin (Site 462); they are exclusively in Cenozoic sediments, and in areas where extensive reworking of shallow-water sediments has been recorded in deep-sea drill sites (Fig. 6). The maximum difference between the age of the reworked material and the time of displacement is greater than $50 \mathrm{~m} . y$. in late Oligocene deposits of Site 462 .

Occurrences of contemporaneous shallow-water-derived carbonate fossils have been observed in sediments ranging from Barremian-Aptian to Quaternary age. They are not evenly distributed in age, but seem to prefer specific time spans. The earliest event has been observed in Barremian-Albian time, the next during the Cenomanian. Intensive displacement of shallow-water carbonates took place during Campanian and Maastrichtian times, but decreased sharply towards the Cretaceous/Tertiary boundary. Paleocene deposits have not produced evidence for reworked shallow-water carbonates in the central Pacific ocean, but this might be the result of many and extensive hiatuses over this interval, developed during erosion in the deep sea (Fig. 8). During the Cenozoic, the flux of shallow-water components was particularly important during the early Eocene, late Eocene, late Oligocene, late Miocene, and 

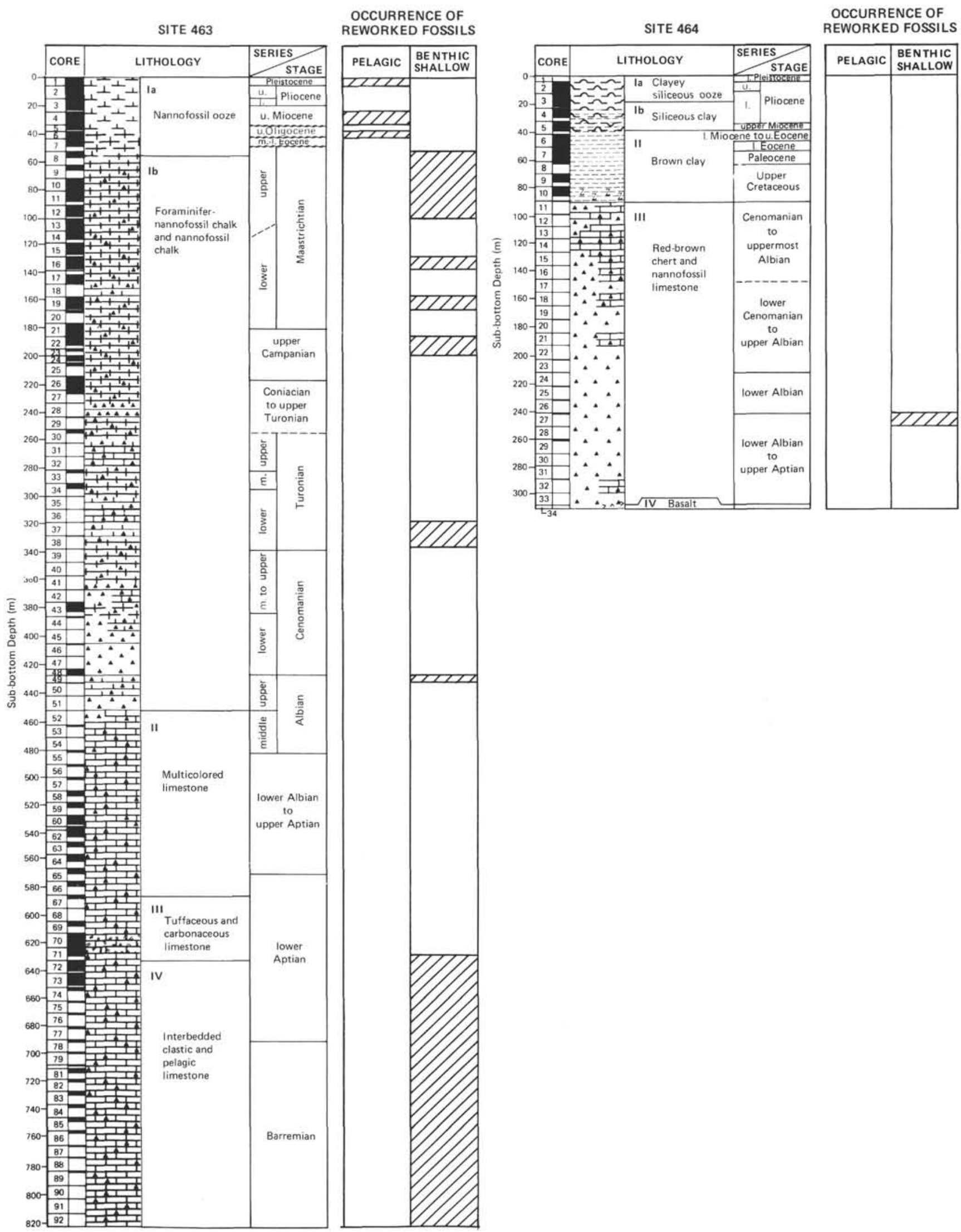

Figure 2. Distribution of reworked and displaced planktonic and shallow-water-derived benthic fossils at DSDP Leg 62 sites in the central North Pacific Ocean (see Fig. 1 and Table 2). 

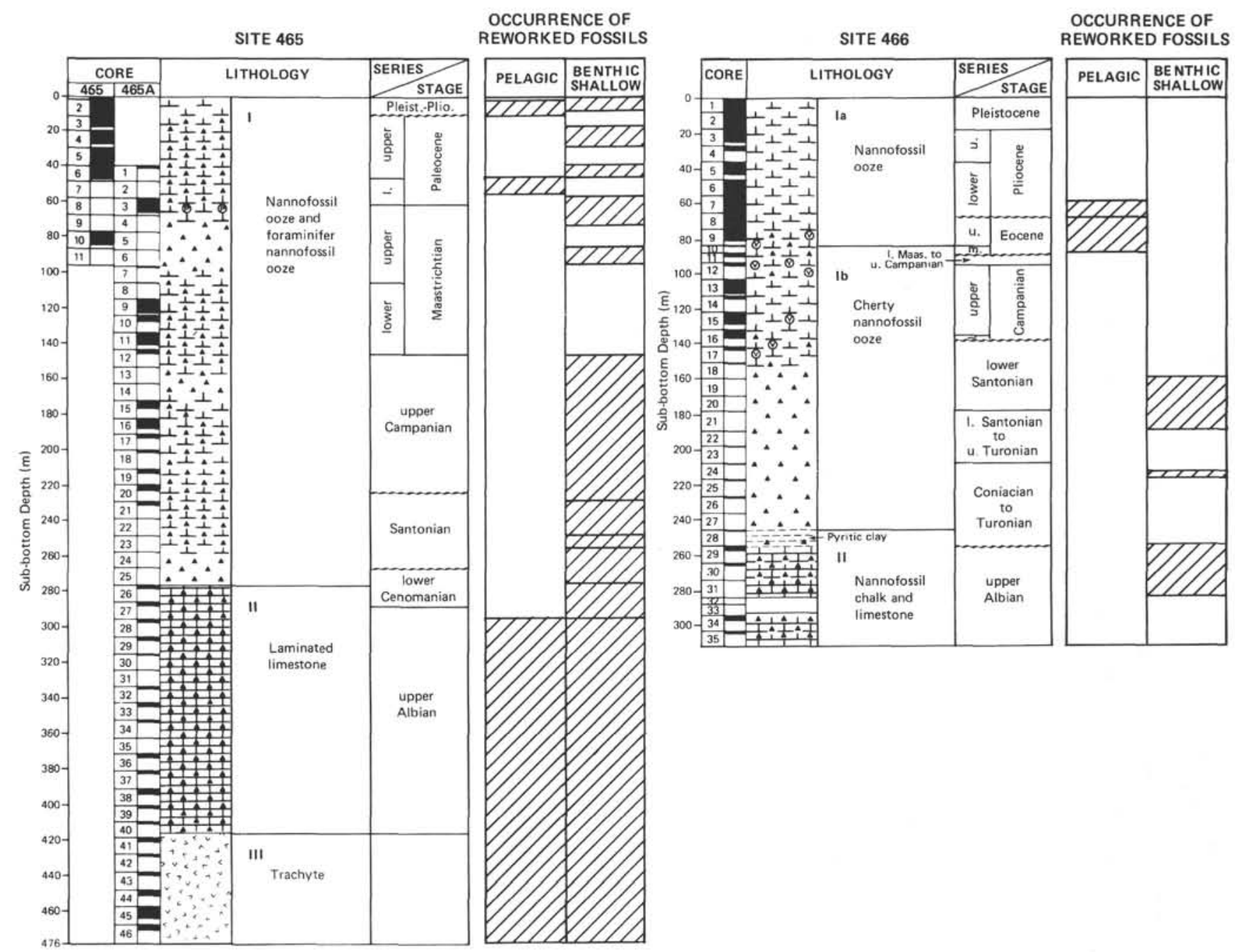

Figure 2. (Continued).

Plio-Pleistocene (Fig. 6). It seems particularly notable that the influx of shallow-water carbonate fossil debris during the entire time span considered here occurred in pulses, and that it represented a sequence of episodic events rather than a continuous process.

The composition of the shallow-water carbonate fossil debris displaced into the deep sea changed considerably with time. The Cretaceous events eroded mainly remains of coralline and green algae, large benthic foraminifers (Asterorbis, Pseudorbitoides, Sulperculina, Vaughanina), corals, ostracodes, echinoids, bryozoans, mollusks (especially bivalves such as Inoceramus and rudists). Rich Mesozoic shallow-water fossil assemblages have been found at Sites 171, 317, 462, and 463 . The Tertiary and Quaternary events, insofar as they did not cut into upper Mesozoic sedimentary strata, resulted in a transfer of much poorer fossil assemblages into the deep sea-mainly coralline algae, large and small benthic foraminifers (Assilina, Amphistegina, Asterocyclina, Discocyclina, Elphidium, Heterostegina, Lepidocyclina, Miogypsinoides, Nummulites, Operculina), corals, bryozoans, ostracodes, bivalves, and echinoderms. Diverse and abundant Cenozoic shallow-water fossil as- semblages have been found for example at Sites 165 , 318 , and 462 . The displaced mollusks, corals, and other macrofossils usually are fragmented, but they can occur as clasts of several centimeters' diameter in horizons in reworked material, and they therefore are easily observed in the relatively fine-grained deep-sea sediments.

\section{Occurrences and Composition of Displaced Pelagic Sediment Components in Deep-Sea Drill Sites from the Tropical and Subtropical Pacific Ocean}

The distribution patterns of reworked and displaced fossils produced by oceanic plankton (Fig. 7) are very different from those of fossil debris derived from shallow-water regions (Fig. 6). The occurrences of displaced pelagic fossils (Fig. 7) include observations made on all major four pelagic microfossil groups (diatoms, radiolarians, coccoliths, foraminifers), whose grain-size spectra range from silt- to sand-sized material. Most observations $(\sim 80 \%)$, however, have been obtained from occurrences of reworked coccoliths and planktonic foraminifers, and to a minor degree from radiolarians. The information presented is therefore biased toward the depositional environments of calcareous oozes above 

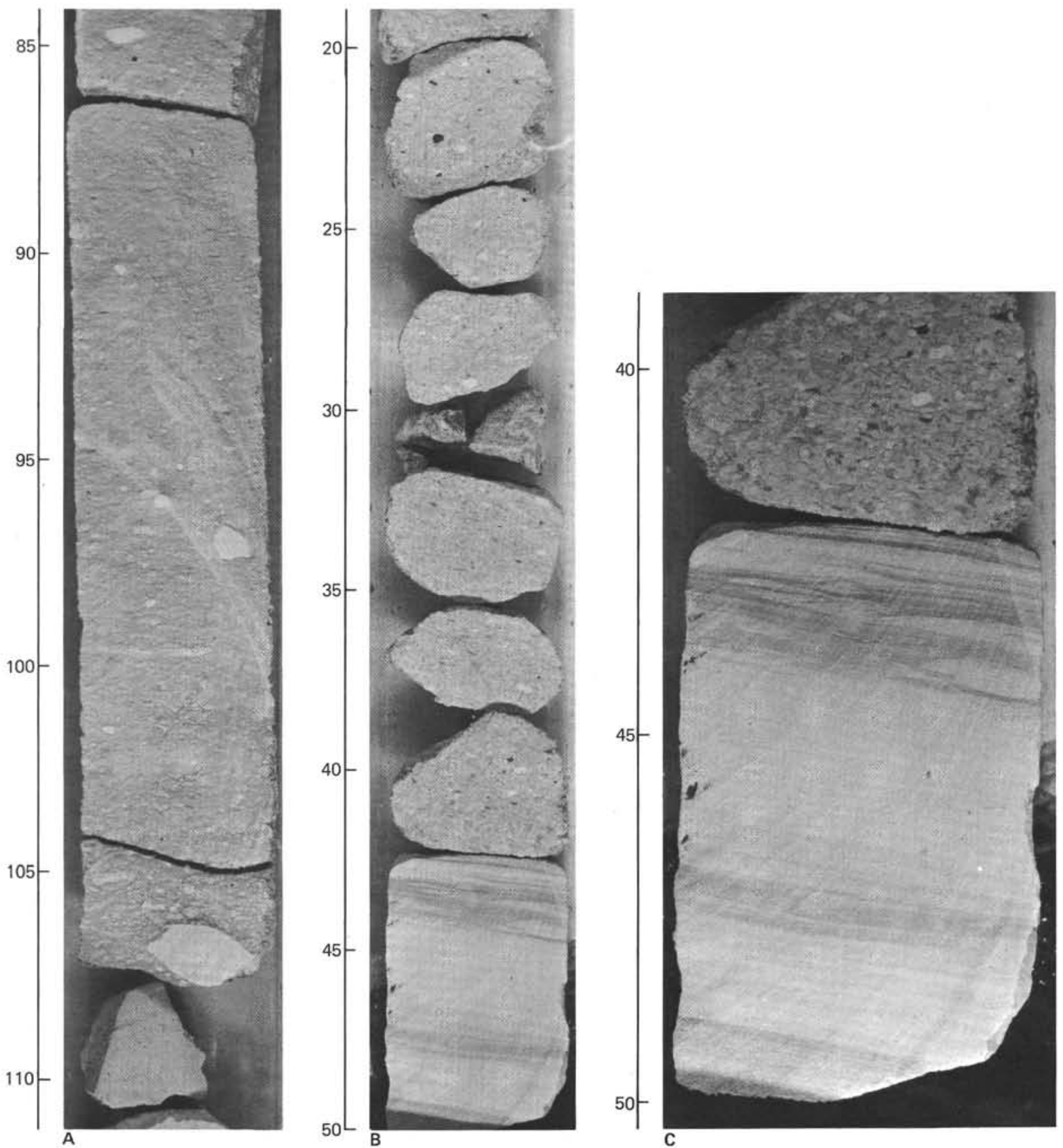

Figure 3. Clastic shallow-water-derived limestone conglomerates interbedded with Barremian and lower Aptian pelagic limestones, Site 463 (Mid-Pacific Mountains). A. 463-81-1, 85-115 cm. B. 463-85-1, 120-150 cm. C. Detail of B (140-150 cm). D. 463-85-2, $30-40 \mathrm{~cm}$. E. $463-85-2,120-140 \mathrm{~cm}$. F. $463-86-1,35-50 \mathrm{~cm}$.

the CCD and under the influence of intermediate (Reid, 1965), but not the deepest water masses.

Although we know from textural studies that the surface sediments of the modern ocean bottom are intensively reworked, this cannot be documented as easily for older ocean floors. Even though sedimentary structures in deep-sea drill cores often indicate bottom-water currents, the amount of reworking and displacement of contemporaneous biogenic components is difficult to detect and to assess. However, if reworked fossils are considerably older (non-contemporaneous) than the deep-sea sediments, they can be used as an unequivocal argument for current transport. The properties of the eroded sediments and sediment particles are evidence for the strength of the reworking current regimes. In Figure 7, we have plotted therefore only observations of non-contemporaneous reworked fossils, which can be as much as $70 \mathrm{~m}$.y. older than the host sediment.

The most surprising feature of the distributions of reworked non-contemporaneous pelagic fossils in the central Pacific Ocean (Fig. 7) is the almost complete lack of such redeposited pelagic fossil material from most of the Mesozoic part of the penetrated sections. The earliest occurrences were observed in Maastrichtian sediments, but the number of observations remains modest until the late middle Eocene, when a major episode of 

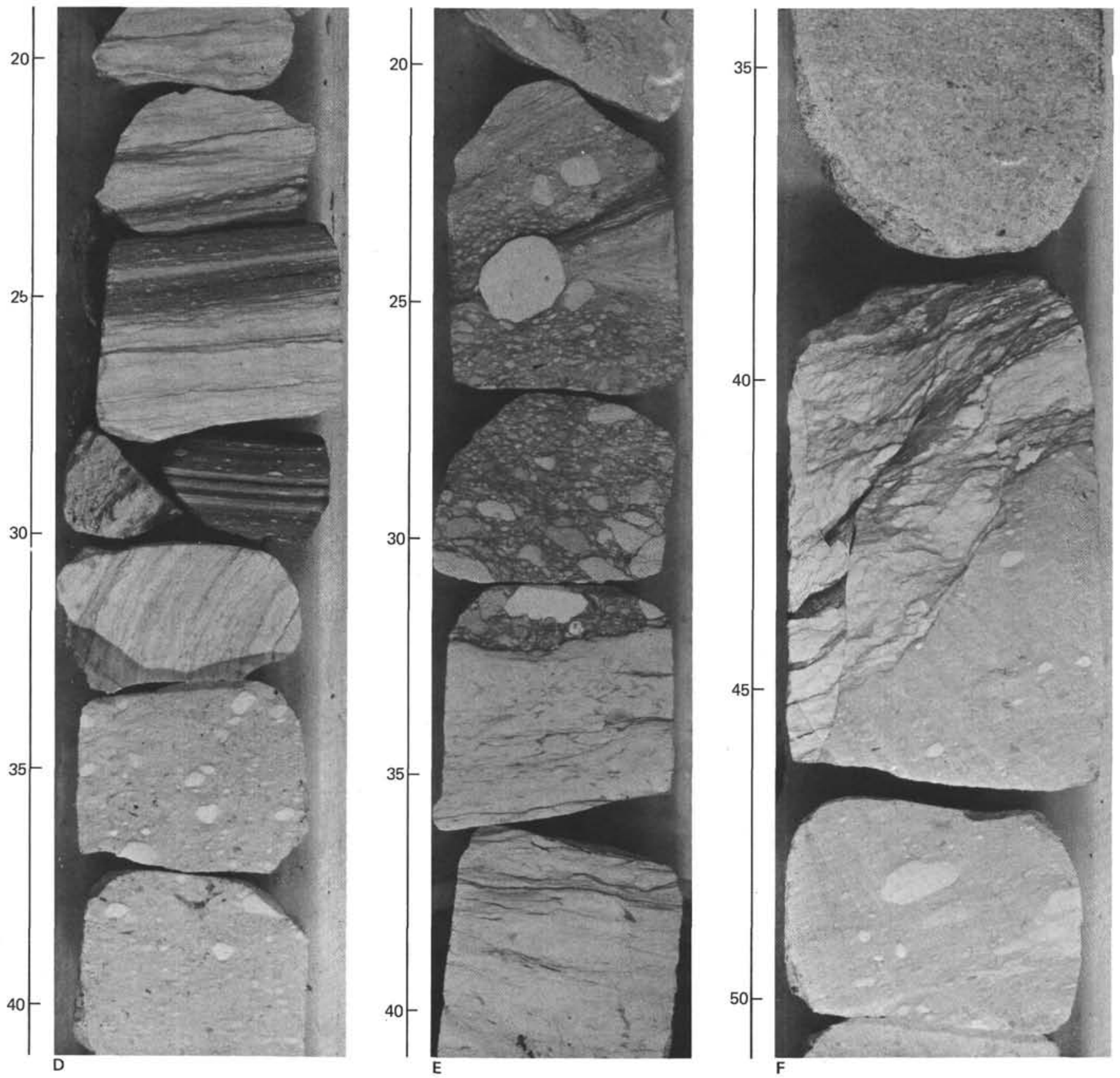

Figure 3. (Continued).

erosion in the meso- and bathypelagic water masses of the central Pacific Ocean began. The planktonic-foraminifer faunas of many sites therefore bear ample evidence of widespread reworking of Eocene to Cretaceous faunas (Krasheninnikov, this volume). The past $40 \mathrm{~m}$.y. has been a time of constant reworking of deep-sea sediments (Fig. 7), with peaks of erosion at approximately 40 m.y., 30 to $32 \mathrm{~m} . y ., 14$ to $15 \mathrm{~m} . y ., 7$ to 8 m.y., and during the past 5 m.y. The number of observations from the intervals 10 to $13 \mathrm{~m} . \mathrm{y}$. , and in particular from 15 to $25 \mathrm{~m} . \mathrm{y}$. and 33 to $38 \mathrm{~m}$.y., are relatively small.

The difference between the age of the eroded section and the time of final deposition of the reworked mate- rial can obviously range over a wide time span, and the precision of this variable is dependent upon the detail of available stratigraphic data. In this context, it has to be kept in mind that the biostratigraphic zonations of $\mathrm{Me}$ sozoic deep-sea sediments are considerably less refined (van Hinte, 1976) than the Cenozoic ones (Hardenbol and Berggren, 1978; Berggren and Van Couvering, 1974). It is therefore obvious that the Mesozoic and Cenozoic data from the central Pacific Ocean cannot be compared easily.

The age difference of the reworked material and time of displacement in general can range between zero (reworking of contemporaneous or penecontemporaneous deposits) and a maximum value determined by the dif- 


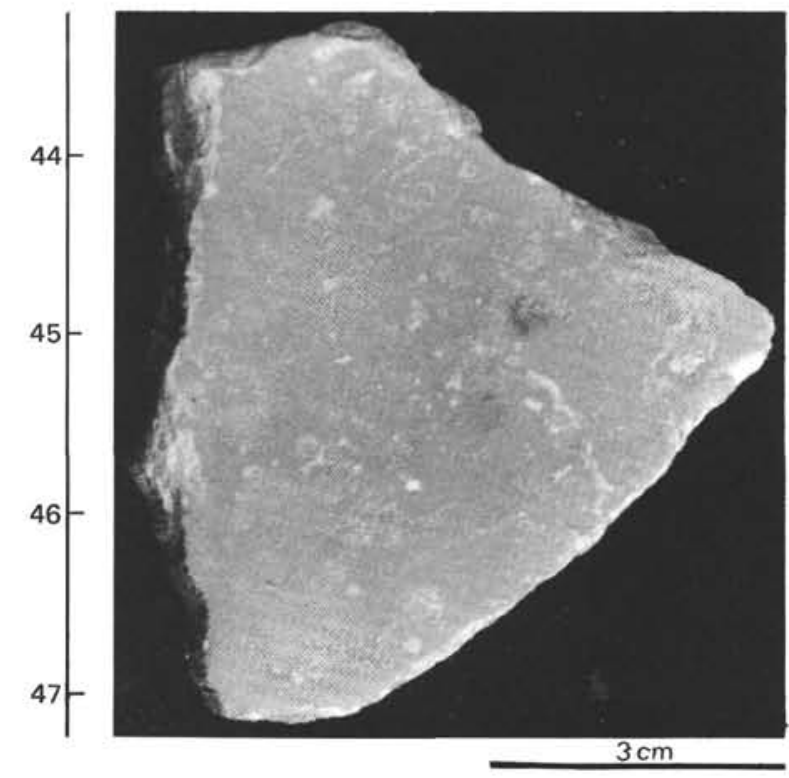

Figure 4. Large Inoceramus fragment from Maastrichtian sediments of Hole 465A.

ference in age of the oldest eroded sediments and the time of deposition of the reworked components. It seems to be characteristic of the central Pacific Ocean that there was no age difference between reworked and host sediments during most of the Mesozoic part of the penetrated sedimentary section, and that only coeval sediments-if any-have been reworked. Only since Maastrichtian time, when fossils from upper Campanian deposits were incorporated into the chalks and calcareous oozes, has a major age difference begun to develop. The maximum age difference between oldest reworked fossil components and the host sediment increased in a regular fashion from the Maastrichtian to approximately $38 \mathrm{~m} . \mathrm{y}$. ago in late Eocene time, when it reached 30 to $40 \mathrm{~m}$.y. Between the late Eocene and the late Pliocene to early Pleistocene, the maximum age difference fluctuated between 20 and 70 m.y. High age differences (Fig. 7) were reached in the late Eocene and early Oligocene, during the early to middle Miocene, and at the end of the Pliocene, whereas minimal values are confined to times when the number of observations of reworked pelagic material was reduced in general. A drastic decrease of the maximum difference in age of the reworked sediment components and the host sediment during the early and late Pleistocene, which already had been observed at Site 462 in the Nauru Basin (Rea and Thiede, 1981), can also be seen in the data collected here; this seems to be a general feature of the redeposition of older pelagic deposits in the central Pacific Ocean.

\section{THE OCCURRENCE OF REWORKED AND DISPLACED FOSSILS IN THE MESOZOIC AND CENOZOIC OF THE CENTRAL PACIFIC OCEAN: IMPLICATIONS FOR PALEOCEANOGRAPHY}

The survey (Tables 2 and 3 ) of reworked and displaced pelagic and shallow-water benthic fossils in the central Pacific Ocean in upper Mesozoic and Cenozoic pelagic sediments is by no means complete, but the collected data come from 47 deep-sea sites drilled during 15 DSDP legs, and they therefore are considered a representative sample of observations collected largely by the shipboard sedimentologists and paleontologists. Even though the observations from any single leg might be biased because of the personal interests of the scientists involved, the type of presence-absence data used in this study would tend to remove most of the bias.

Reworked and displaced shallow-water benthic fossils which are found in deep-sea sediments from the central Pacific Ocean bear evidence of the former presence and nature of the many depositional environments of shoals which once reached into the photic zone and which once were the locales of extensive carbonate deposition (Matthews et al., 1974; Hamilton, 1956). The presence of such shallow-water carbonates has been documented by deep-sea drill sites and by extensive dredging. Most of the central Pacific guyots have been found to be made up of Lower and Upper Cretaceous carbonates (Heezen et al., 1973) and volcanic rocks of highly variable composition (Natland, 1976; Jackson and Schlanger, 1976). It has been assumed that most of the late Mesozoic shallow-water carbonate environments have ceased to exist as a result of submergence (Matthews et al., 1974), owing to rapid eustatic sea-level rises.

In Figure 6, we have plotted the occurrences of shallow-water-derived benthic fossils from a considerable number of drill sites in the western central Pacific Ocean (Fig. 5; Table 3). The data document repeated injection of shallow-water debris into the adjacent deepsea basins throughout the late Mesozoic and the entire Cenozoic in a sequence of short-lived, episodic events which are separated from each other by intervals when less or no shallow-water-derived benthic-fossil material reached the floor of the deep-sea basins. The events, except the Campanian-Maastrichtian one, coincide with low eustatic sea-level stands (Vail et al., 1977), and they therefore represent erosion close to the lowered sea level during those intervals. The Campanian-Maastrichtian event is a special case, because it is the most important one of the late Mesozoic paleoenvironment; it apparently did not coincide with very low eustatic sea levels (Vail et al., 1977; McCoy and Zimmermann, 1977), but it preceded an interval of important hiatuses in the central Pacific Ocean across the Cretaceous/Tertiary boundary (Fig. 8). However, this interval was coeval with a major phase of widespread volcanic activity (Jackson and Schlanger, 1976) in the central Pacific Ocean, which led to the deposition of volcanic ash in the Mariana Basin (Site 199), along the Line Islands (Sites 165, 315, and 316), and on Horizon Guyot (Sites 171 and 313).

The occurrence of shallow-water benthic-fossil debris not coeval with this time of redeposition in central Pacific Ocean deep-sea sediments is restricted entirely to the Cenozoic parts of a few drill sites (Fig. 6), for example Sites 76, 165, 209, 315, and 462. This may document events of particularly low eustatic sea-level stands. Because of the locations of these sites in regions of old oceanic crust, subsidence did not generate important 
Table 3. Distribution of hiatuses and reworked fossil material at DSDP Sites in the tropical and subtropical Pacific Ocean. Where not specifically indicated, the data of this table have been extracted from site reports of the respective DSDP legs.

\begin{tabular}{|c|c|c|c|c|c|c|c|}
\hline Leg & Site & $\begin{array}{l}\text { Water } \\
\text { Depth } \\
\text { (m) }\end{array}$ & Hiatuses & Time of Deposition & $\begin{array}{c}\text { Age of Reworked } \\
\text { Shallow-Water Fossils }\end{array}$ & $\begin{array}{l}\text { Age of Reworked } \\
\text { Pelagic Fossils }\end{array}$ & Source \\
\hline \multirow[t]{2}{*}{6} & 47 & 2689 & $\begin{array}{l}\text { Early Miocene-late Eocene, } \\
\text { early Paleocene-late } \\
\text { Maastrichtian }\end{array}$ & Late Maastrichtian & Contemporaneous & & \\
\hline & 48 & 2619 & $\begin{array}{l}\text { Early Miocene- } \\
\text { Maastrichtian }\end{array}$ & Middle Maastrichtian & Contemporaneous & & \\
\hline \multirow[t]{4}{*}{7} & 65 & 6130 & & $\begin{array}{l}\text { Quaternary-middle } \\
\text { Miocene }\end{array}$ & & Middle Eocene & \\
\hline & & & & $\begin{array}{l}\text { Oligocene-late } \\
\text { Eocene }\end{array}$ & & $\begin{array}{l}\text { Eocene/Oligocene-late } \\
\text { Cretaceous }\end{array}$ & \\
\hline & 66 & 5923 & & Quaternary & & $\begin{array}{l}\text { Cretaceous } \\
\text { Miocene }\end{array}$ & \\
\hline & & & & Late late Miocene & & Eocene & \\
\hline 9 & 76 & 4598 & & Pliocene & Eocene & Miocene-Eocene & $\begin{array}{l}\text { See also Site } \\
318 \text { report }\end{array}$ \\
\hline \multirow[t]{9}{*}{17} & 164 & 5944 & $\begin{array}{l}\text { Quaternary-middle Miocene, } \\
\text { late Oligocene, Paleo- } \\
\text { cene-Maastrichtian }\end{array}$ & & & & \\
\hline & 165 & 5053 & $\begin{array}{l}\text { Quaternary-middle Miocene, } \\
\text { Paleocene-Maastrichtian }\end{array}$ & Late Oligocene & & $\begin{array}{l}\text { Eocene and } \\
\text { Maastrichtian }\end{array}$ & \\
\hline & & & & Early Oligocene & Late-middle Eocene & $\begin{array}{l}\text { Oligocene- } \\
\text { Maastrichtian }\end{array}$ & \\
\hline & & & & $\begin{array}{l}\text { Early Maastrichtian- } \\
\text { late Campanian }\end{array}$ & Contemporaneous & & \\
\hline & 166 & 4962 & Turonian-early Oligocene & $\begin{array}{l}\text { Cenomanian-late } \\
\text { Albian }\end{array}$ & & Contemporaneous & \\
\hline & 167 & 3176 & Early Eocene & $\begin{array}{l}\text { Quaternary-late } \\
\text { Pliocene }\end{array}$ & & Miocene and Eocene & \\
\hline & & & & $\begin{array}{l}\text { Middle-early } \\
\text { Campanian }\end{array}$ & Contemporaneous & & \\
\hline & 171 & 2290 & & Middle Eocene & & $\begin{array}{l}\text { Early Eocene- } \\
\text { Maastrichtian }\end{array}$ & \\
\hline & & & & $\begin{array}{l}\text { Late Campanian } \\
\text { Cenomanian }\end{array}$ & $\begin{array}{l}\text { Contemporaneous } \\
\text { Contemporaneous }\end{array}$ & & \\
\hline \multirow[t]{2}{*}{20} & 199 & 6090 & Middle Miocene-early & Late Miocene & & Oligocene-Eocene & \\
\hline & & & $\begin{array}{l}\text { Eocene, early Paleocene- } \\
\text { early Maastrichtian }\end{array}$ & $\begin{array}{l}\text { Middle Miocene } \\
\text { Late Paleocene }\end{array}$ & & $\begin{array}{l}\text { Early Miocene- } \\
\quad \text { Paleocene } \\
\text { Early Paleocene- } \\
\quad \text { late } \\
\quad \text { Cretaceous }\end{array}$ & \\
\hline \multirow[t]{9}{*}{21} & 204 & 5354 & & Quaternary & & Maastrichtian & \\
\hline & & & & $\begin{array}{l}\text { Early Miocene- } \\
\text { Oligocene }\end{array}$ & & Late Cretaceous & \\
\hline & & & & Early(?) Cretaceous & Contemporaneous & & \\
\hline & 205 & 4320 & Middle-early Miocene & $\begin{array}{l}\text { Early late-early } \\
\text { Miocene }\end{array}$ & Contemporaneous & & \\
\hline & 206 & 3196 & $\begin{array}{l}\text { Early Oligocene-late } \\
\text { Eocene }\end{array}$ & Early Miocene & & & \\
\hline & 207 & 1389 & $\begin{array}{l}\text { Early Miocene-late } \\
\text { Eocene }\end{array}$ & $\begin{array}{l}\text { Early middle Miocene } \\
\text { Early Paleocene }\end{array}$ & & $\begin{array}{l}\text { Early late Eocene } \\
\text { Maastrichtian }\end{array}$ & \\
\hline & 208 & 1545 & $\begin{array}{l}\text { Early Oligocene-middle } \\
\text { Eocene, early Eocene- } \\
\text { late Paleocene, early } \\
\text { Paleocene-late } \\
\text { Maastrichtian }\end{array}$ & & & & \\
\hline & 209 & 1428 & $\begin{array}{l}\text { Late Oligocene-late } \\
\text { Eocene }\end{array}$ & Late Oligocene & Contemporaneous & & \\
\hline & 210 & 4643 & $\begin{array}{l}\text { Early Oligocene-late } \\
\text { Eocene }\end{array}$ & $\begin{array}{l}\text { Pleistocene-late } \\
\text { Miocene }\end{array}$ & Contemporaneous & Eocene & \\
\hline \multirow[t]{9}{*}{30} & 285 & 4658 & & Late Miocene & Contemporaneous & $\begin{array}{l}\text { Middle Miocene-late } \\
\text { Oligocene }\end{array}$ & \\
\hline & 286 & 4465 & & Plio-Pleistocene & Contemporaneous & Middle Eocene & \\
\hline & & & & $\begin{array}{l}\text { Late-early Oligocene } \\
\text { Middle Eocene }\end{array}$ & $\begin{array}{l}\text { Contemporaneous } \\
\text { Contemporaneous }\end{array}$ & & \\
\hline & 287 & 4632 & $\begin{array}{l}\text { Early Oligocene-middle } \\
\text { Eocene }\end{array}$ & $\begin{array}{l}\text { Pleistocene-late } \\
\text { Miocene }\end{array}$ & & Oligocene & \\
\hline & 288 & 3000 & $\begin{array}{l}\text { Late Eocene-late } \\
\text { Paleocene }\end{array}$ & Late Pliocene & & $\begin{array}{l}\text { Late early Pliocene- } \\
\text { Cretaceous }\end{array}$ & \\
\hline & & & & Middle Miocene & & $\begin{array}{l}\text { Early Eocene- } \\
\text { Maastrichtian }\end{array}$ & \\
\hline & & & & Early Miocene & & $\begin{array}{l}\text { Early Miocene-late } \\
\text { Cretaceous }\end{array}$ & \\
\hline & & & & Late Oligocene & & $\begin{array}{l}\text { Late Oligocene-early } \\
\text { Eocene }\end{array}$ & \\
\hline & & & & Early Oligocene & & Late early Eocene & \\
\hline
\end{tabular}


Table 3. (Continued).

\begin{tabular}{|c|c|c|c|c|c|c|c|}
\hline Leg & Site & $\begin{array}{c}\text { Water } \\
\text { Depth } \\
\text { (m) }\end{array}$ & Hiatuses & Time of Deposition & $\begin{array}{c}\text { Age of Reworked } \\
\text { Shallow-Water Fossils }\end{array}$ & $\begin{array}{l}\text { Age of Reworked } \\
\text { Pelagic Fossils }\end{array}$ & Source \\
\hline \multirow[t]{10}{*}{32} & 305 & 2903 & $\begin{array}{l}\text { Early Miocene-late Oligo- } \\
\text { cene, middle Eocene }\end{array}$ & Late middle Miocene & & Oligocene & \\
\hline & 306 & 3399 & Quaternary-late Albian & & & & \\
\hline & 307 & 5696 & $\begin{array}{l}\text { Quaternary-early } \\
\text { Cenomanian }\end{array}$ & & & & \\
\hline & 308 & 1331 & Pleistocene-early Eocene & Early Eocene & Contemporaneous & & \\
\hline & 309 & 1454 & & Quaternary & $\begin{array}{l}\text { Early Miocene-late } \\
\text { Oligocene }\end{array}$ & Miocene(?) & \\
\hline & 310 & 3516 & $\begin{array}{l}\text { Middle Miocene-Oligocene, } \\
\text { Oligocene-middle } \\
\text { Eocene, early Eocene- } \\
\text { Maastrichtian }\end{array}$ & Late-middle Eocene & & $\begin{array}{c}\text { Early Eocene and } \\
\text { Maastrichtian }\end{array}$ & \\
\hline & 313 & 3484 & Middle-early Eocene, early & Quaternary & & No ages available & \\
\hline & & & Eocene-middle & Early middle & & & \\
\hline & & & Maastrichtian & Miocene & & & \\
\hline & & & & Late-middle Miocene & & & \\
\hline \multirow[t]{16}{*}{33} & 314 & 5214 & Quaternary-Eocene & Pliocene & & Paleocene & Kaneps (1976) \\
\hline & 315 & 4152 & Late Paleocene-middle & Late Oligocene & Campanian & & Beckmann (1976) \\
\hline & & & Maastrichtian & Early Oligocene & Late Cretaceous & Late Cretaceous & Beckmann (1976) \\
\hline & & & & Middle Maastrichtian & Late Cretaceous & Late Cretaceous & Beckmann (1976) \\
\hline & 316 & 4451 & Middle Miocene, late- & Late Miocene & & Early-middle Miocene & Kaneps (1976) \\
\hline & & & $\begin{array}{l}\text { early Oligocene, early } \\
\text { Oligocene-middle }\end{array}$ & $\begin{array}{l}\text { Early Paleocene } \\
\text { Early Maastrichtian- }\end{array}$ & Contemporaneous & Cretaceous(?) & Beckmann (1976) \\
\hline & & & $\begin{array}{l}\text { Eocene, early Paleocene- } \\
\text { late Campanian }\end{array}$ & late Campanian & & & \\
\hline & 317 & 2598 & & Early Cretaceous & Contemporaneous & & Kauffmann (1976) \\
\hline & 318 & 2641 & $\begin{array}{l}\text { Middle-early Miocene, late } \\
\text { late Oligocene-late }\end{array}$ & $\begin{array}{l}\text { Quaternary-late } \\
\text { Pliocene }\end{array}$ & Contemporaneous & & Beckmann (1976) \\
\hline & & & Eocene, middle Eocene & $\begin{array}{l}\text { Early Pliocene-late } \\
\text { Oligocene }\end{array}$ & & Middle Eocene & \\
\hline & & & & Middle-early & & Early Miocene-late & \\
\hline & & & & Miocene & & Oligocene & \\
\hline & & & & Early Miocene & Contemporaneous & & Beckmann (1976) \\
\hline & & & & Late Eocene & Contemporaneous & & Beckmann (1976) \\
\hline & & & & Middle Eocene & Contemporaneous & Middle-early Eocene & Beckmann (1976) \\
\hline & & & & Early Eocene & Contemporaneous & & Beckmann (1976) \\
\hline \multirow[t]{2}{*}{57} & 439 & 1656 & Quaternary-late Miocene & Early Miocene & & Cretaceous & \\
\hline & 441 & 5655 & & $\begin{array}{l}\text { Early Pliocene-late } \\
\text { Miocene }\end{array}$ & & $\begin{array}{l}\text { Early middle-late } \\
\text { early Miocene }\end{array}$ & \\
\hline \multirow[t]{9}{*}{58} & 443 & 4372 & & $\begin{array}{l}\text { Early Pliocene-late } \\
\text { Miocene }\end{array}$ & Contemporaneous & Late early Miocene & \\
\hline & 444 & 4843 & & Pleistocene & & Pliocene-Miocene & \\
\hline & & & & Late Miocene & & Early middle Miocene & \\
\hline & 445 & 3377 & & Quaternary & & Pliocene & \\
\hline & & & & $\begin{array}{l}\text { Oligocene-middle } \\
\text { Eocene }\end{array}$ & Contemporaneous & & \\
\hline & 446 & 4952 & Quaternary & Late Miocene & & Middle Miocene & \\
\hline & & & & Middle Oligocene & & $\begin{array}{l}\text { Early Oligocene and } \\
\text { Eocene }\end{array}$ & \\
\hline & & & & Early late Eocene & Contemporaneous & & \\
\hline & & & & Late early Eocene & & Late Cretaceous & \\
\hline 59 & 451 & 2060 & & $\begin{array}{l}\text { Quaternary-late } \\
\text { Miocene }\end{array}$ & Contemporaneous & $\begin{array}{l}\text { Pliocene-middle } \\
\text { Miocene }\end{array}$ & \\
\hline \multirow[t]{4}{*}{60} & 458 & 3449 & & Pliocene, late & & No age available & \\
\hline & & & & Miocene & Oligocene & & \\
\hline & & & & Oligocene & Oingecene & Early Eocene & \\
\hline & 460 & 6443 & & Eocene & & Cretaceous & \\
\hline 61 & 462 & 5190 & $\begin{array}{l}\text { Late Pliocene-late Miocene, } \\
\text { late-middle Miocene, } \\
\text { middle-early Miocene, } \\
\text { late Paleocene- } \\
\text { Maastrichtian }\end{array}$ & $\begin{array}{c}\text { Quaternary-late } \\
\text { Campanian }\end{array}$ & $\begin{array}{l}\text { Early Miocene-late } \\
\text { Campanian }\end{array}$ & $\begin{array}{l}\text { Late Miocene-late } \\
\text { Campanian }\end{array}$ & $\begin{array}{l}\text { Premoli Silva and } \\
\text { Brusa (1981) } \\
\text { Rea and Thiede } \\
\text { (1981) }\end{array}$ \\
\hline
\end{tabular}

differences in depth of deposition during the later part of the Mesozoic and during Cenozoic, so that erosion during low eustatic sea-level stands was able to reach the older strata.

Erosional events as a consequence of sea-level changes, or their coeval occurrence, also have often been invoked to explain major changes of oceanic bottom- water current regimes. In comparing the timing of the occurrences of non-contemporaneous pelagic fossils (Fig. 7) with those of benthic shallow-water-derived fossils (Fig. 6) in the central Pacific Ocean, this coincidence cannot be confirmed, but the curves seem to be independent of each other. This incompatibility of both data sets, however, might have to do with the fact 


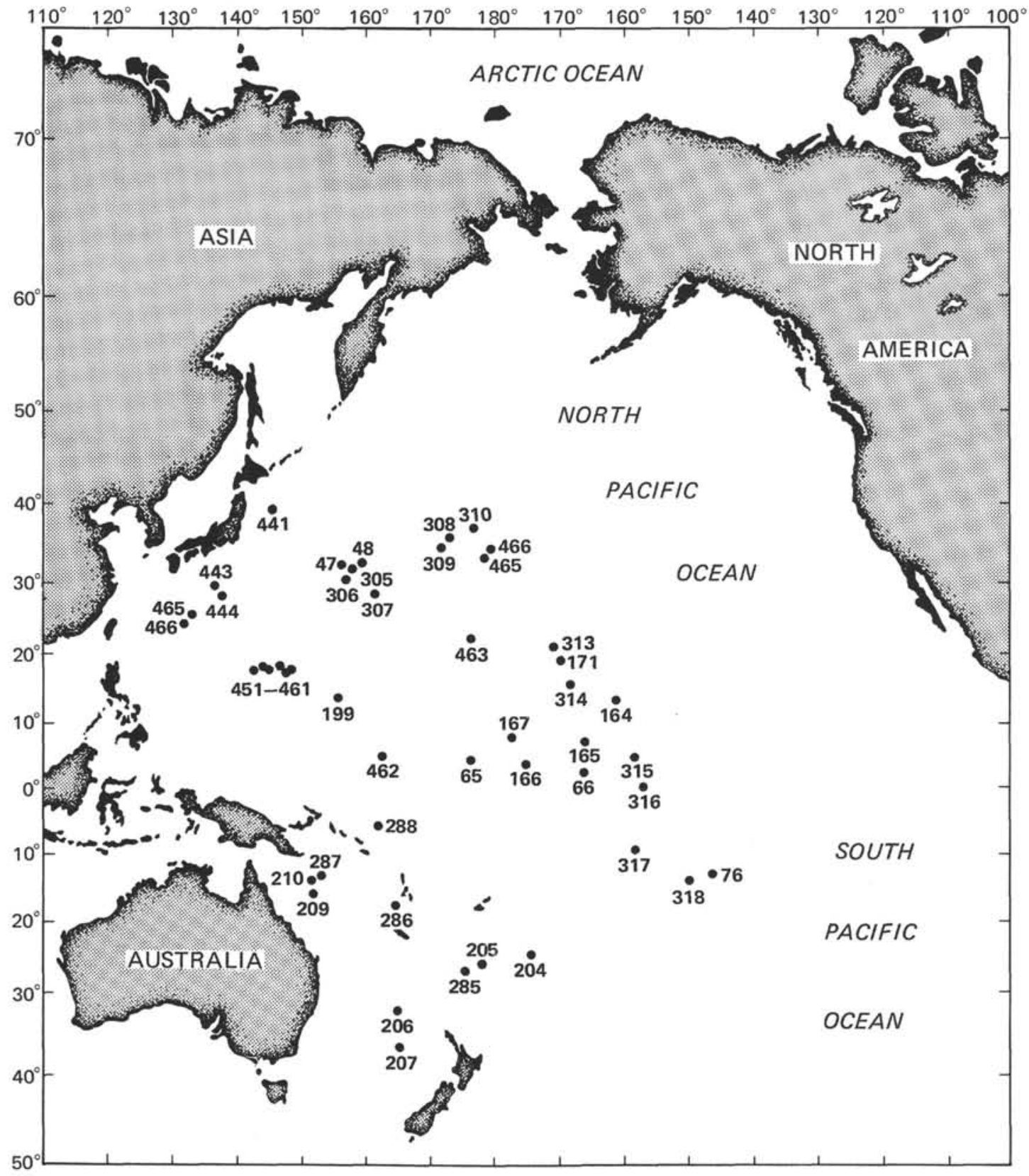

Figure 5. Locations of DSDP drill sites in the subtropical and tropical central western Pacific Ocean, discussed in this paper.

that reworked coeval pelagic biogenic sediment components only rarely can be distinguished from autochthonous components if sedimentary structures and textural characteristics are not used as supportive evidence. Contemporaneous reworking and displacement in pelagic sediments has often been underrated, because of the lack of suitable data-mostly because of the lack of stratigraphic resolution. However, the dominance of occurrences of penecontemporaneous reworked fossils (radiolarians) throughout the Tertiary in a large collection of sediment cores (Table 4) from the tropical Pacific Ocean (Riedel, 1971) can be explained only by the fact that the youngest sediments available for erosion during each time span are also those eroded most extensively. The same data set (Table 4) indicates also that the temporal distribution of erosional events in the deep sea is very irregular through time, because reworked Cretaceous or Paleocene radiolarians have been found in very few instances, and because Pliocene sediments seem to be less affected by reworking than Miocene and Eocene sediments. The deep-sea drill-site data compiled in Tables 2 and 3 and illustrated in Figure 7 have added considerable stratigraphic detail to this preliminary interpretation, but it has to be kept in mind that most of the radiolarian data displayed in Table 4 have been obtained from non-calcareous sediments, in contrast to the deep-sea drill-site data, which are dominantly from calcareous deposits. Both sets of data therefore have been obtained from different depositional paleodepth levels in the ocean. 


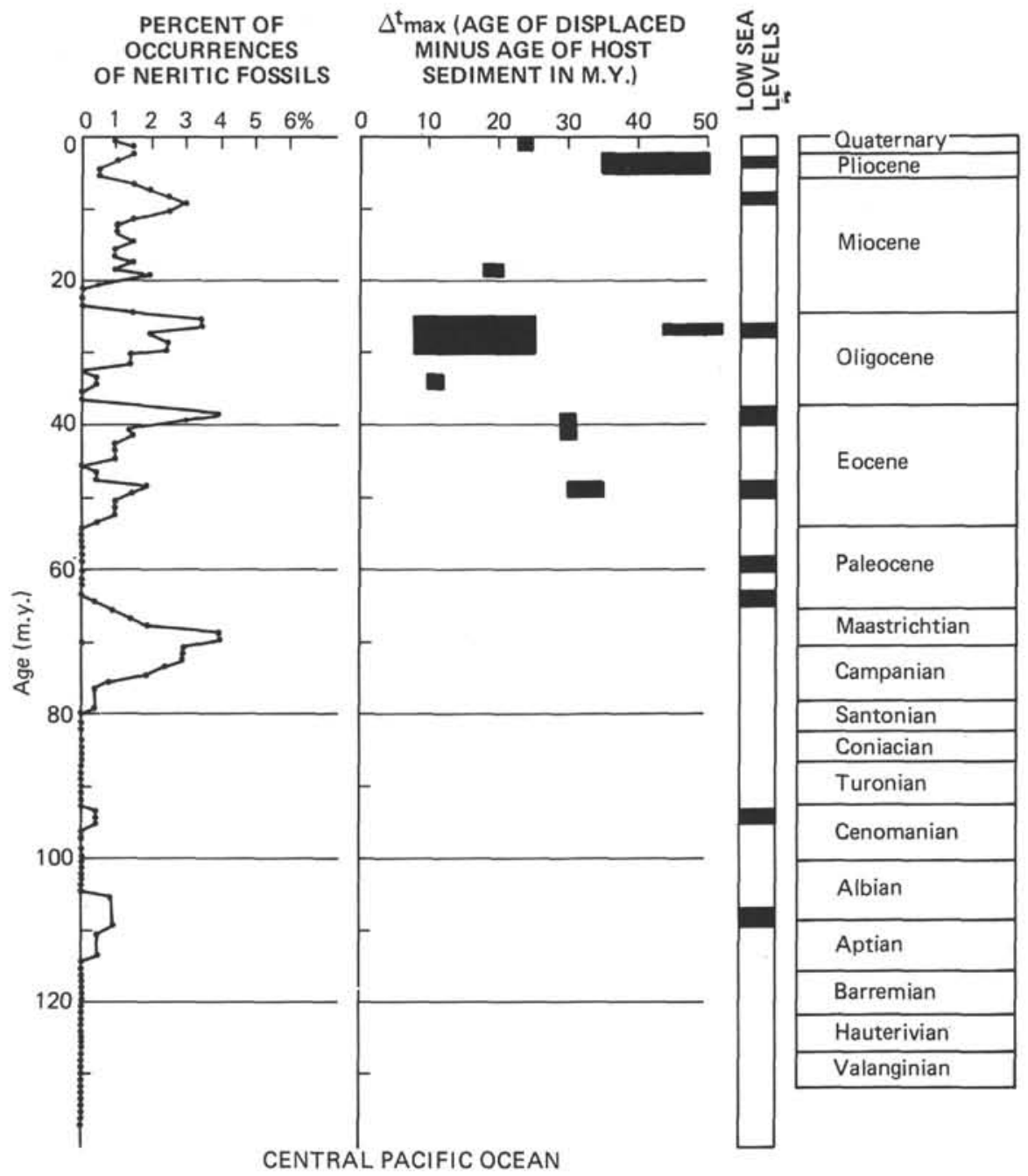

Figure 6. Occurrence and age of displaced shallow-water fossils in drill sites from the subtropical and tropical central western Pacific Ocean. Occurrence is expressed in percent of total observations. $\Delta t_{\max }$ is the maximum time difference between the age of the reworked and displaced material and the time of redeposition. The ages of low eustatic sea-level stands according to Vail et al. (1977) have been marked on the right side of the figure.

The most surprising aspect of the distribution of noncoeval reworked pelagic sediment components in the central Pacific Ocean is the large difference between the Mesozoic and the Cenozoic strata (Fig. 7). Maastrichtian events which reworked the immediately underlying Campanian sediments obviously represent the beginning of current regimes in the intermediate water masses of the Pacific Ocean, which were able not only to transport and displace coeval sediments, but also to erode the underlying older sediments. This is different from the South Atlantic paleoenvironment, where pelagic sediments as old as Coniacian have been displaced into deposits of Santonian age (Premoli Silva and Boersma, 1977). Even though the available drill-site data (Tables 2 and 3) have to be considered preliminary, the large quantitative difference of occurrences of redeposited and reworked planktonic fossils during pre-Maastrichtian and Maastrichtian-Pleistocene time seems to point to a fundamental change of the depositional paleoenvironment of the deep central Pacific Ocean, and prob- ably of the world ocean in general. If the physical properties of deep-sea sediments (Schlanger and Douglas, 1974) deposited during the pre-Campanian time in the central Pacific Ocean were not drastically different from those laid down during the past 75 m.y., then their erosional potential should have been approximately the same. If diagenetic changes have effected the erosional potential of the pre-Campanian central Pacific deep-sea sediments, then these diagenetic changes must have occurred soon after deposition of these sediments. The coincidence of the lack of non-coeval reworked pelagic fossil material and of the repeated development of oxygen-deficient depositional environments between 80 and 120 m.y., which must have been accompanied by a very quiet and sluggish bottom-water circulation, as documented by their laminated sediments (Dean et al., this volume), seems to support the interpretation that a wide area of the pre-Campanian central Pacific Ocean has not experienced bottom-water currents strong enough to erode older strata and to transport the re-suspended 


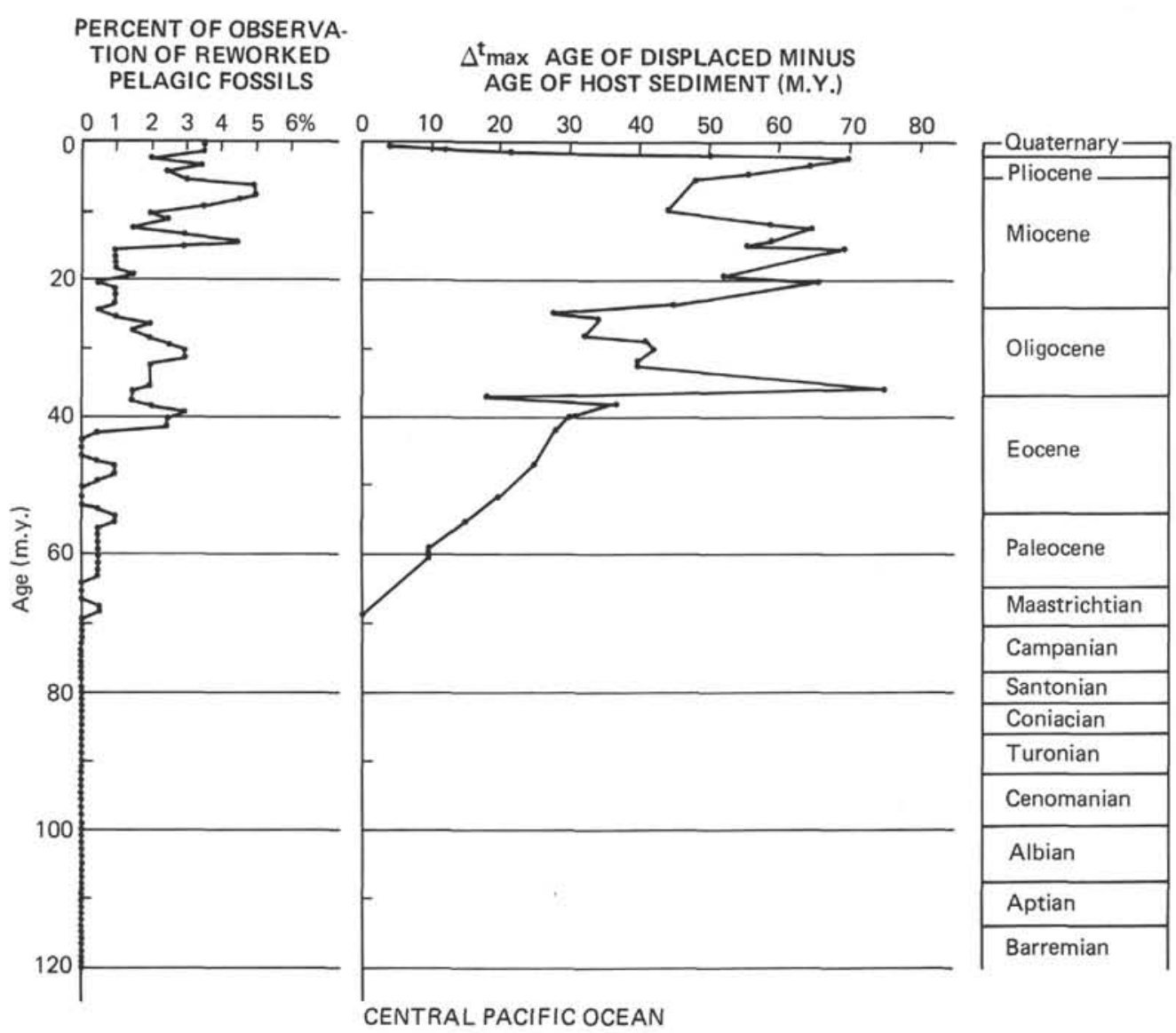

Figure 7. Occurrence of non-contemporaneous reworked pelagic fossils (calcareous nannofossils, planktonic foraminifers, and radiolarians) at drill sites of the subtropical and tropical central western Pacific Ocean. Occurrence is expressed in percent of total observations. $\Delta t_{\max }$ is the maximum time difference between the age of the reworked material and the time of redeposition.

sediment particles. Relatively rapid currents seem to have been confined to the upper few hundreds of meters of the water column, especially close to the equatorial divergence (Dean et al., this volume).

The number of occurrences of reworked non-coeval pelagic fossils (Fig. 7) remained modest from Maastrichtian to late middle Eocene times, but minor peaks during the late Paleocene and early middle Eocene represent short-lived erosional events of a modest scale. The remainder of the Cenozoic was characterized by depositional paleoenvironments with erosion at intermediate water depths as the rule, not the exception. The late middle and early late Eocene, early late Oligocene, early middle Miocene, middle late Miocene, Pliocene and Quaternary were times of particularly strong reworking in the central Pacific Ocean, whereas the late Oligocene to early Miocene seems to have been rather quiescent. The coincidence of times of important reworking with major changes of the oceanic bottomwater temperature (Fig. 9), as deduced from the $\delta \mathrm{O}^{18}$ ratios of the benthonic foraminifers (Savin, 1977; Vincent and Berger, in press), suggests that these episodes represent major revolutions of the bottom-water current regimes, because of advection of cold polar bottom waters (Shackleton and Kennett, 1975). It has to remain open at the present time if the pre-late middle Eocene reworking events can be explained by the formation of modest quantities of polar bottom waters much earlier than hitherto presumed.

The age distribution of the reworked and displaced non-coeval pelagic fossils and the difference between the age of reworked components and time of redeposition in the central Pacific Ocean are particularly interesting (Fig. 7). The time difference can vary between zero and a certain maximum value, as it reflects the length of the stratigraphic column which was subject to erosion at the time of redeposition. In the central $\mathrm{Pa}$ cific Ocean, this age difference approached zero during Maastrichtian time, but increased fairly regularly throughout the Cenozoic to the early Pleistocene. The regular increase must mean that the entire sediment column which had been laid down since initiation of this erosional regime in early Maastrichtian time was subject to continuous erosion and redeposition. Deviations from the regular increase of the maximum time difference between the age of the reworked material and time of redeposition have been observed for the early and late Oligocene, as well as the late Miocene and Quaternary. Minima of this curve (Fig. 7) coincide with episodes of high pelagic accumulation rates (van Andel et al., 1975; Worsley and Davies, 1979), the maxima with the development of important hiatuses in the western 


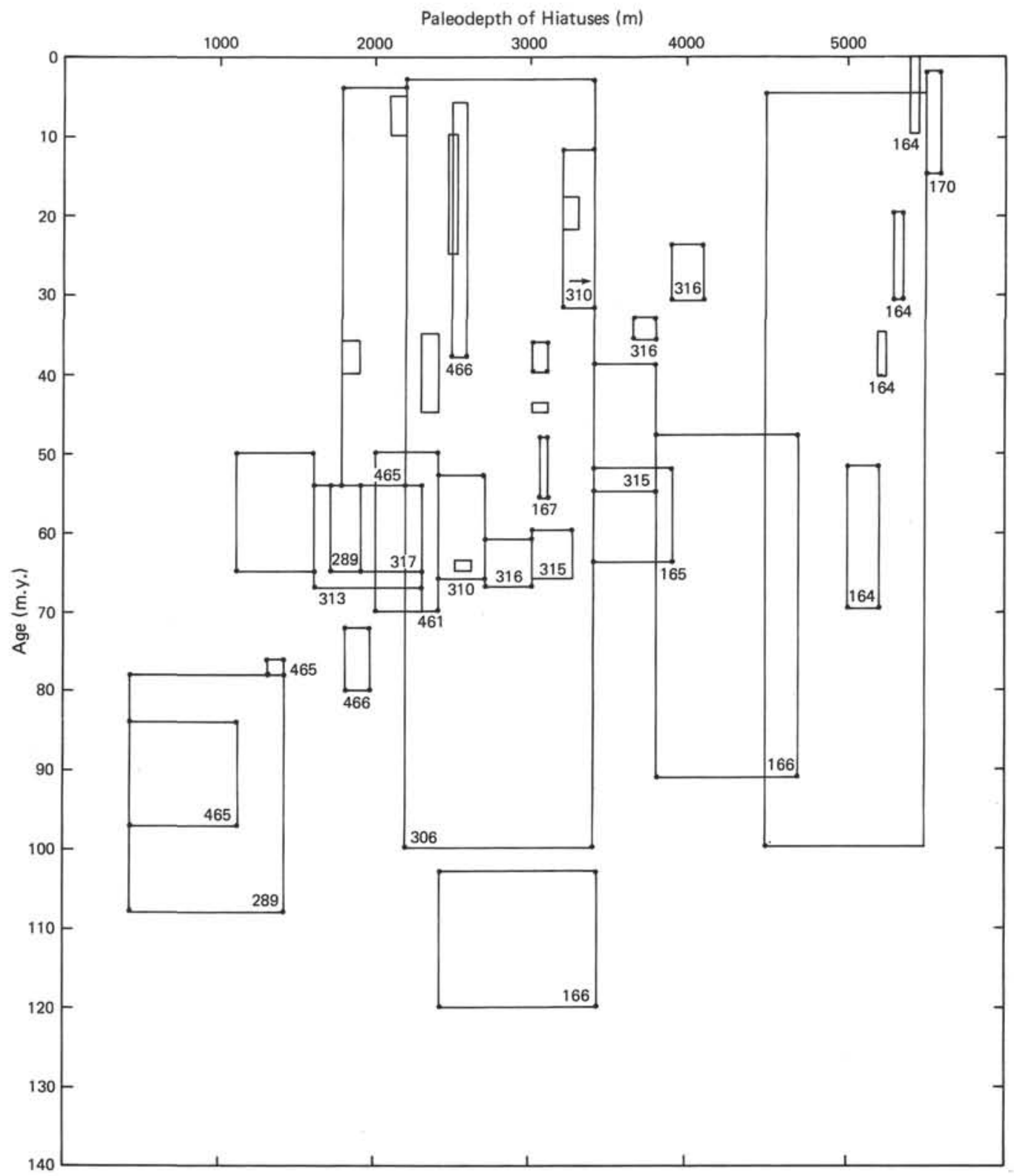

Figure 8. Paleodepth and age distribution of major hiatuses in the central North Pacific Ocean. The diagram depicts the time span of major hiatuses and their paleodepth range. Hiatuses are marked with their site numbers.

Table 4. Temporal distribution of samples containing pre-Quaternary radiolarians (dominantly cores from the tropical Pacific Ocean). Data from Riedel (1971). Values are percent of observations.

\begin{tabular}{|c|c|c|c|c|c|c|c|}
\hline \multirow{2}{*}{$\begin{array}{c}\text { Age of } \\
\text { Displacement }\end{array}$} & \multicolumn{6}{|c|}{ Age of Reworked Radiolarians } & \multirow{2}{*}{$\begin{array}{c}\text { Total } \\
\text { Observation }\end{array}$} \\
\hline & Pliocene & Miocene & Oligocene & Eocene & Paleocene & Cretaceous & \\
\hline \multicolumn{8}{|l|}{ Quaternary } \\
\hline Calcareous ooze & 12 & 29 & 24 & 34 & 0 & 1 & 119 \\
\hline Siliceous ooze & 16 & 30 & 21 & 32 & 0 & 0 & 145 \\
\hline Clay & 7 & 21 & 21 & 48 & 0 & 0 & 149 \\
\hline Total & 12 & 27 & 22 & 39 & 0 & 1 & 413 \\
\hline Pliocene & 41 & 29 & 10 & 19 & 0 & 1 & 121 \\
\hline Miocene & & 62 & 13 & 25 & 0 & 0 & 100 \\
\hline Oligocene & & & 69 & 31 & 0 & 0 & 35 \\
\hline Eocene & & & & 100 & 0 & 0 & 14 \\
\hline Paleocene & & & & & 0 & 0 & 0 \\
\hline Cretaceous & & & & & & & 1 \\
\hline
\end{tabular}




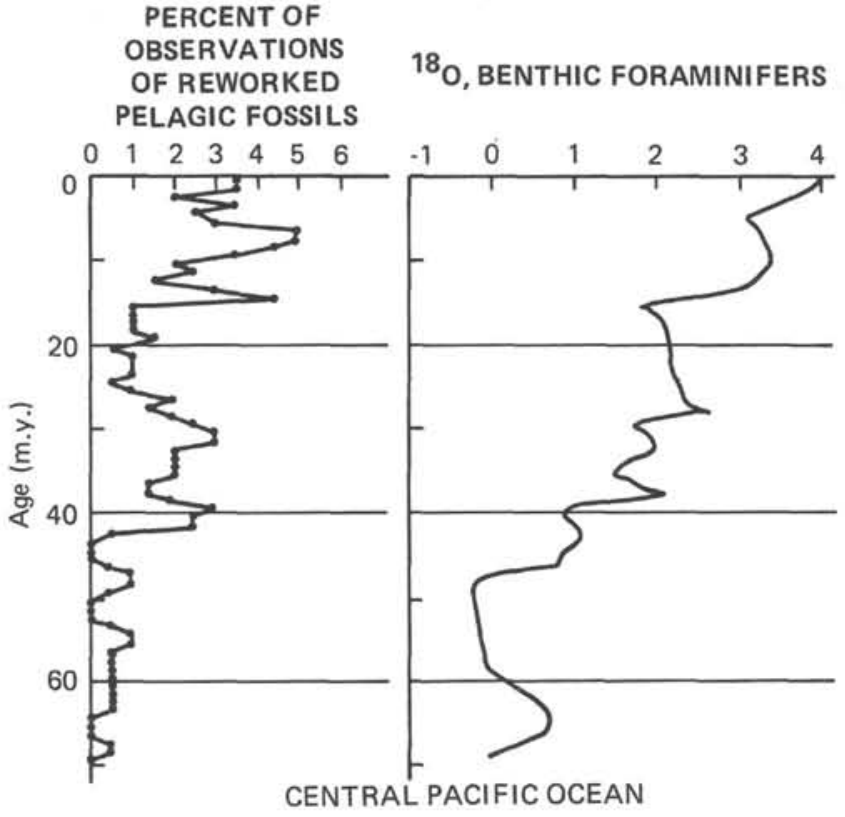

Figure 9. Oxygen-isotope ratios in benthic foraminifers through the past 70 m.y. Most measurements have been made on material from the North Pacific Ocean (after Vincent and Berger, in press; Savin, 1977).

central Pacific Ocean (Moore et al., 1978). The unique simplicity of the argument that reworked and displaced non-coeval fossils in deep-sea sediments imply mechanical transport suggests that mechanical erosion caused most of these hiatuses, rather than non-deposition or dissolution.

\section{CONCLUSIONS}

1. Reworked and displaced fossils are accessory but common components of tropical and subtropical central western Pacific Ocean deep-sea sediments. They consist both of coeval and non-contemporaneous pelagic and shallow-water-derived benthic calcareous fossils. Their presence in fine-grained deep-sea sediments implies mechanical transport from their original locale to the site of their final deposition.

2. The composition of the displaced neritic fossil assemblages changed considerably with time from the Cretaceous to the Tertiary. This allows description of the evolution of the shallow-water depositional environments of guyots and carbonate platforms in the tropical and subtropical central western Pacific Ocean.

3. Neritic fossils were transported episodically from guyots and shoals into the adjacent deep sea during times of low eustatic sea-level stands. Erosional events which reworked non-coeval neritic deposits considerably older than the age of redeposition are confined to the Cenozoic.

4. A major late Campanian-Maastrichtian erosional event possibly is not related to low global sea levels, but to an episode of major volcanic activity in the central western Pacific. Sediments of an apparently complete section across the Cretaceous/Tertiary boundary penetrated at Site 465 on southern Hess Rise do not contain reworked material.
5. Reworking and displacement of coeval planktonic fossils is often difficult to detect in dominantly biogenic deep-sea sediments. A regime of erosion which cut into non-coeval, older sediments-defined by displaced zone fossils-developed in the central western Pacific Ocean only during Maastrichtian time. The coincidence of the development and spread of oxygen-deficient depositional environments, which led to preservation of laminated, very fine-grained sediments, with the lack of indications of important mechanical erosion during the pre-Maastrichtian Cretaceous suggests very slow intermediate water current regimes.

6. The erosional potential of the central western Pacific Ocean depositional environments during the pre-Maastrichtian part of the Cretaceous was drastically different from that of post-Campanian time, when noncoeval sediments were continuously eroded mechanically from outcrops on the ocean floor. Times of high sediment-accumulation rates coincided with a decrease of the length of the stratigraphic columns available for erosion during the past 70 m.y.

7. The Maastrichtian and lower Tertiary pre-middle Eocene erosional regime of the central western Pacific Ocean suggests formation of modest quantities of cool to cold bottom water from the polar regions much earlier than hitherto presumed. The coincidence of abundant reworked pelagic fossils with major changes of the oxygen-isotope ratios of benthic foraminifers, and hence of the bottom-water temperatures during the Cenozoic, points to the importance of advection of cool to cold water masses of polar (Antarctic) origin to the intermediate waters of the central western Pacific Ocean. This advection resulted in more-rapid currents which eroded the ocean floor and generated widespread hiatuses through reworking and mechanical redeposition of biogenic sediments, rather than through dissolution.

\section{ACKNOWLEDGMENTS}

This study is based on data collected during DSDP Leg 62 and descriptions of deep-sea drill sites from other DSDP legs in the tropical and subtropical central Pacific Ocean. The effort to collect these data has therefore been shared by numerous colleagues, whose skillful work is gratefully acknowledged. These ideas have been discussed with W. H. Berger, Scripps Institution of Oceanography, and P. Vail, Exxon-Houston, whose comments are appreciated.

\section{REFERENCES}

Beckmann, J. P., 1976. Shallow-water foraminifers and associated microfossils from Sites 315, 316, and 318, DSDP Leg 33. In Schlanger, S. O., Jackson, E. D., et al., Init. Repts. DSDP, 33: Washington (U.S. Govt. Printing Office), 467-470.

Berggren, W. A., and Van Couvering, J. A., 1974. The late Neogene: biostratigraphy, biochronology and paleoclimatology of the last 15 million years in marine and continental sediments. Palaeogeography, Palaeoecology, Palaeoclimatology, 16:1-216.

Boltovskoy, E., 1977. Neogene deep water benthonic foraminifera of the Indian Ocean. In Heirtzler, J. B. (Ed.), Indian Ocean Geology and Biostratigraphy: Washington (Am. Geophys. Union), pp. 599-616.

Burckle, L. H., and Stanton, D., 1975. Distribution of displaced Antarctic diatoms in the Argentine basin. Nova Hedwigia Beih., 53: 283-292.

Cook, H. E., Jenkyns, H. C., and Kelts, K. R., 1975. Redeposited sediments along the Line Islands, equatorial Pacific. In Schlanger, S. O., Jackson, E. D., et al., Init. Repts. DSDP, 33: Washington (U.S. Govt. Printing Office), 837-847. 
Hamilton, E. L., 1956. Sunken Islands of the Mid-Pacific Mountains. Geol. Soc. Am. Mem., 64.

Hardenbol, J., and Berggren, W. A., 1978. A new Paleogene numerical time scale. Am. Assoc. Petrol. Geol. Stud. Geol., 6:213-234.

Heezen, B. C., Matthews, J. L., Catalano, R., et al., 1973. Western Pacific guyots. In Heezen, B. C., MacGregor, I. D., et al., Init. Repts. DSDP, 20: Washington (U.S. Govt. Printing Office), 653723.

Jackson, E. D., and Schlanger, S. O., 1976. Regional syntheses, Line Islands chain, Tuamotu Islands chain, and Manihiki Plateau, central Pacific Ocean. In Schlanger, S. O., Jackson, E. D., et al., Init. Repts. DSDP, 33: Washington (U.S. Govt. Printing Office), 915-927.

Kaneps, A. G., 1976. Cenozoic planktonic foraminifers, equatorial Pacific Ocean, Leg 33, DSDP. In Schlanger, S. O., Jackson, E. D., et al., Init. Repts. DSDP, 33: Washington (U.S. Govt. Printing Office), 361-367.

Kauffman, E. G., 1976. Deep-sea Cretaceous macrofossils: Hole 317A, Manihiki Plateau. In Schlanger, S. O., Jackson, E. D., et al., Init. Repts. DSDP, 33: Washington (U.S. Govt. Printing Office), 503-535.

Lancelot, Y., 1978. Relations entre évolution sédimentaire et tectonique de la plaque Pacifique depuis la Crétacée inferieur. Soc. Géol. France Mém., N. S., 134.

Lancelot, Y., and Larson, R. L., 1975. Sedimentary and tectonic evolution of the northwestern Pacific. In Larson, R. L., Moberly, R. et al., Init. Repts. DSDP, 32: Washington (U.S. Govt. Printing Office), 925-939.

McCoy, F. W., and Zimmerman, H. B., 1977. A history of sediment lithofacies in the South Atlantic Ocean. In Supko, P. R., PerchNielsen, K., et al., Init. Repts DSDP, 39: Washington (U.S. Govt. Printing Office), 1047-1079.

Matthews, J. O., Heezen, B. C., Catalano, R., et al., 1974. Cretaceous drowning of reefs on Mid-Pacific and Japanese guyots. Science, 184: 462-464.

Moore, T. C., van Andel, Tj. H., Sancetta, C., et al., 1978. Cenozoic hiatuses in pelagic sediments. Micropaleontology, 24:113-138.

Natland, J. H., 1976. Petrology of volcanic rocks dredged from seamounts in the Line Islands. In Schlanger, S. O., Jackson, E. D., et al., Init. Repts. DSDP, 33: Washington (U.S. Govt. Printing Office), 749-777.

Pitman, W. C., Larson, R. L., and Herron, E. M., 1974. Magnetic Lineations of the Oceans: Geol. Soc. Am. Map Ser.

Premoli Silva, I., and Boersma, A., 1977. Cretaceous planktonic foraminifers-DSDP Leg 39 (South Atlantic). In Supko, P. R., PerchNielsen, K., et al., Init. Repts. DSDP, 39: Washington (U.S. Govt. Printing Office), 615-641.

Premoli Silva, I., and Brusa, C., 1981. Shallow-water skeletal debris and larger foraminifers from the Deep-Sea Drilling Project Site 462, Nauru Basin, western equatorial Pacific. In Larson, R. L., Schlanger, S. O., et al., Init. Repts. DSDP, 61: Washington (U.S. Govt. Printing Office), 397-422.

Rea, D. K., and Thiede, J., 1981. Mesozoic and Cenozoic massaccumulation rates of the major sediment components in the Nauru Basin, western equatorial Pacific. In Larson, R. L.,
Schlanger, S. O., et al., Init. Repts. DSDP, 61: Washington (U.S. Govt. Printing Office), 549-556.

Reid, J. L., 1965. Intermediate Waters of the Pacific Ocean. Johns Hopkins Oceanogr. Stud., 2.

Riedel, W. R., 1971. The occurrence of pre-Quaternary radiolaria in deep-sea sediments. In Funnell, B. M., and Riedel, W. R. (Eds.), The Micropaleontology of Oceans: Cambridge (Cambridge Univ. Press), pp. 567-594.

Savin, S. M., 1977. The history of the Earth's surface temperature during the past 100 million years. Ann. Rev. Earth Planet. Sci., 5:319-355.

Schlanger, S. O., and Douglas, R. G., 1974. The pelagic ooze-chalklimestone transition and its implications for marine stratigraphy. Internat. Assoc. Sedimentol. Spec. Publ, 1:117-148.

Schlanger, S. O., and Premoli Silva, I., 1981. Tectonic, volcanic, and paleogeographic implications of redeposited reef faunas of Late Cretaceous and Tertiary age from the Nauru Basin and the Line Islands. In Larson, R. L., Schlanger, S. O., et al., Init. Repts. DSDP, 61: Washington (U.S. Govt. Printing Office), 817-828.

Seibold, E., 1978. Mechanical processes influencing the distribution of pelagic sediments. Micropaleontology, 24:407-421.

Shackleton, N. J., and Kennett, J. P., 1975. Paleotemperature history of the Cenozoic and the initiation of Antarctic glaciation: oxygen and carbon isotope analyses in DSDP Sites 277, 279 and 281. In Kennett, J. P., Houtz, R. E., et al., Init. Repts. DSDP., 29: Washington (U.S. Govt. Printing Office), 743-755.

Shipboard Scientific Party, in press. Site 462: Nauru Basin, Western Pacific Ocean, Deep Sea Drilling Project Leg 61. In Larson, R. L., Schlanger, S. O., et al., Init. Repts. DSDP, 61: Washington (U.S. Printing Office).

Thiede, J., 1977. Textural variations of calcareous coarse fractions in the Panama Basin (eastern equatorial Pacific Ocean). In Andersen, N. R., and Malahoff, A. (Eds.), The Fate of Fossil Fuel $\mathrm{CO}_{2}$ in the Oceans: New York (Plenum), pp. 673-692.

Thiede, J., and Dinkelman, M. E., 1977. Occurrence of Inoceramus remains in late Mesozoic pelagic and hemipelagic sediments. In Supko, P. R., Perch-Nielsen, K., et al., Init. Repts. DSDP, 39: Washington (U.S. Govt. Printing Office), 899-910.

Vail, P. R., Mitchum, R. M., and Thompson, S., 1977. Seismic stratigraphy and global changes of sea level. Part 3: relative changes of sea level from coastal onlap. Part 4: global cycles of relative changes of sea level. Am. Assoc. Petrol. Geol. Mem., 26:63-97.

van Andel, Tj. H., 1973. Texture and dispersal of sediments in the Panama basin. J. Geol., 81:434-457.

van Andel, Tj. H., Heath, G. R., and Moore, T. C., 1975. Cenozoic history and paleoceanography of the central equatorial Pacific Ocean. Geol. Soc. Am. Mem., 143.

van Hinte, J. E., 1976. A Cretaceous time scale. Am. Assoc. Petrol. Geol. Bull., 60:498-516.

Vincent, E., and Berger, W. H., in press. Planktonic foraminifera and their use of paleoceanography. In Emiliani, C. (Ed.), The Sea (Vol. 7): New York (Wiley-Interscience).

Worsley, T. R., and Davies, T. A., 1979. Sea level fluctuations and deep-sea sedimentation rates. Science, 203:455-456. 